\title{
Connexin 43: A Target for the Treatment of Inflammation in Secondary Complications of the Kidney and Eye in Diabetes
}

\author{
Chelsy L. Cliff ${ }^{1,+}$, Bethany M. Williams ${ }^{1,+}{ }^{,}$, Christos E. Chadjichristos ${ }^{2}{ }^{\circledR}$, Ulrik Mouritzen $^{3}$, Paul E. Squires ${ }^{1} \mathbb{C}$ \\ and Claire E. Hills ${ }^{1, *}$ \\ 1 Joseph Banks Laboratories, School of Life, Sciences University of Lincoln, Lincoln LN6 7DL, UK; \\ CCliff@lincoln.ac.uk (C.L.C.); Bewilliams@lincoln.ac.uk (B.M.W.); PSquires@lincoln.ac.uk (P.E.S.) \\ 2 National Institutes for Health and Medical Research, UMR-S1155, Batiment Recherche, Tenon Hospital, \\ 4 Rue de la Chine, 75020 Paris, France; christos.chadjichristos@inserm.fr \\ 3 Ciana Therapeutics, Ole Maaloes Vej 3, 2200 Copenhagen N, Denmark; info@cianatx.com \\ * Correspondence: chills@lincoln.ac.uk \\ + These authors contributed equally to this work.
}

check for

updates

Citation: Cliff, C.L.; Williams, B.M.; Chadjichristos, C.E.; Mouritzen, U.; Squires, P.E.; Hills, C.E. Connexin 43: A Target for the Treatment of Inflammation in Secondary Complications of the Kidney and Eye in Diabetes. Int. J. Mol. Sci. 2022, 23, 600. https://doi.org/10.3390/ ijms 23020600

Academic Editor: Hidayat Hussain

Received: 26 November 2021

Accepted: 4 January 2022

Published: 6 January 2022

Publisher's Note: MDPI stays neutral with regard to jurisdictional claims in published maps and institutional affiliations.

Copyright: (C) 2022 by the authors. Licensee MDPI, Basel, Switzerland. This article is an open access article distributed under the terms and conditions of the Creative Commons Attribution (CC BY) license (https:// creativecommons.org/licenses/by/ $4.0 /)$.

\begin{abstract}
Of increasing prevalence, diabetes is characterised by elevated blood glucose and chronic inflammation that precedes the onset of multiple secondary complications, including those of the kidney and the eye. As the leading cause of end stage renal disease and blindness in the working population, more than ever is there a demand to develop clinical interventions which can both delay and prevent disease progression. Connexins are membrane bound proteins that can form pores (hemichannels) in the cell membrane. Gated by cellular stress and injury, they open under pathophysiological conditions and in doing so release 'danger signals' including adenosine triphosphate into the extracellular environment. Linked to sterile inflammation via activation of the nod-like receptor protein 3 inflammasome, targeting aberrant hemichannel activity and the release of these danger signals has met with favourable outcomes in multiple models of disease, including secondary complications of diabetes. In this review, we provide a comprehensive update on those studies which document a role for aberrant connexin hemichannel activity in the pathogenesis of both diabetic eye and kidney disease, ahead of evaluating the efficacy of blocking connexin- 43 specific hemichannels in these target tissues on tissue health and function.
\end{abstract}

Keywords: diabetes; complications; diabetic nephropathy; diabetic retinopathy; connexin 43; hemichannels; hemichannel blockers; inflammation; purinergic; adenosine triphosphate

\section{Introduction}

Impacting almost $10 \%$ of adults, diabetes is a global healthcare concern that affects an estimated 463 million people worldwide. With the prevalence of diabetes expected to rise to 700 million people by 2045 [1], it is not the treatment of the disease itself, but the management of associated secondary complications which poses the greatest threat to our healthcare system [2]. Disease complications in diabetes can be categorised as either macrovascular or microvascular, with the former associated with coronary artery disease [3], peripheral arterial disease [4], and stroke [5], whilst microvascular complications include nephropathy [6-8], retinopathy $[9,10]$ and impaired wound healing [11,12]. In the early stages of disease progression, management focuses on regulation of blood pressure and maintenance of good glycaemic control [13]. However, for many, deterioration of good health is inevitable, with kidney failure, loss of vision or circulatory problems, contributed to by comorbidities (e.g., hypertension, obesity, cardiovascular disease) and health inequalities [14]. In the absence of a definitive treatment for these conditions, new therapeutic approaches are urgently required.

In diabetes, complications develop in response to sustained hyperglycaemia and low-grade systemic inflammation, the latter of which is heightened in type 2 diabetes melli- 
tus (T2DM), where coupled with obesity, increased adipose tissue secretes inflammatory mediators that exacerbate a state of pre-existing inflammation [15-18]. There is a strong association between microvascular complications in patients with T2DM, and individuals who present with diabetic nephropathy often experience higher incidence of retinopathy compared to patients without any diabetes-related kidney issues [19-22]. Similarly, individuals exhibiting diabetic retinopathy appear more susceptible to the onset of kidney problems [23]. These findings suggest a 'common pathway' representative of systemic microvascular damage and chronic inflammation that, secondary to diabetes, leads to a progressive loss of tissue function. Recent retinopathy and nephropathy studies strongly suggest that blocking expression and/or function of small transmembrane proteins called connexins under pathophysiological conditions, may significantly dampen the inflammatory response that drives disease progression across these and other age associated pathologies, e.g., obesity [24,25], Alzheimer's disease [26,27] and osteoarthritis [28].

Connexins are a family of membrane bound proteins involved in the transfer of small molecules and ions between two cells (gap junctions) and between cells and their immediate environment (hemichannels), highlighted in Figure 1. Nomenclature is dictated by molecular weight [29], with connexin 43 (Cx43) the most abundant in humans [30]. Composed of one intracellular and two extracellular loops, and an N- and C-terminus [31], they oligomerise into hexameric structures called connexons and are delivered to the plasma membrane in vesicles that transit along a secretory pathway [32,33]. When neighbouring cells align, connexons dock to form a continuous gap junction, establishing a direct route for cell-cell communication that allows cells to synchronise their activity [34-36]. Whilst gap junction activity maintains cellular function under physiological conditions undocked connexons, referred to as hemichannels, are typically linked with pathophysiological stimuli, such as oxidative stress [37] and inflammation [35,38]. Dysregulation of hemichannel function is associated with chronic diseases, including deafness [39], brain ischaemia [40] and chronic pain [41,42]. The role of hyperglycaemia in regulating connexin expression [43,44], gap junction communication [45] and hemichannel activity [46-48] is well documented [49], and of the 21 isoforms known to be expressed within the human body, $\mathrm{C} \times 43$ has been strongly linked to the pathogenesis of multiple secondary complications of diabetes [43,50-52]. In this article, we review a role for $\mathrm{Cx} 43$ hemichannels in chronic inflammation and microvascular complications of diabetic nephropathy and retinopathy, ahead of exploring the therapeutic potential of hemichannel blockers in preventing disease progression.

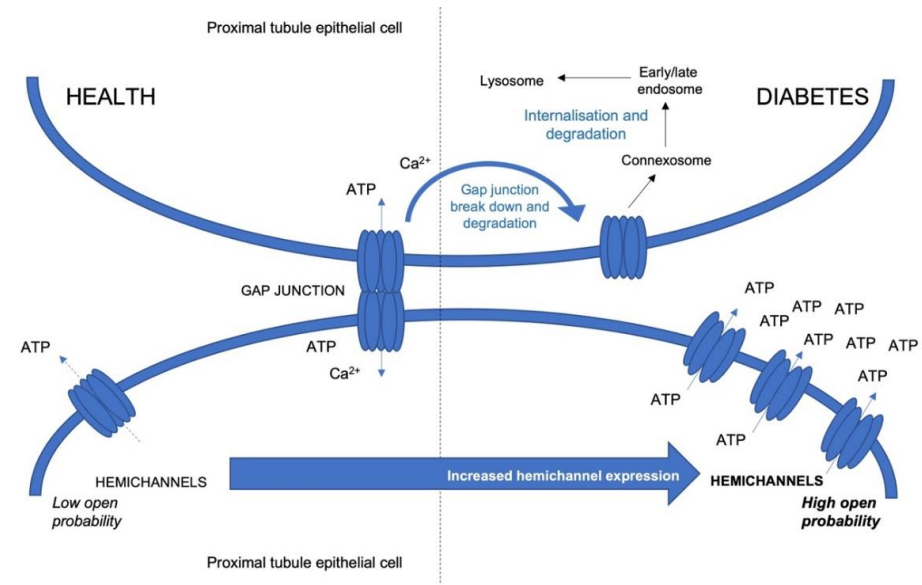

Figure 1. A schematic highlighting changes in hemichannel activity in health and diabetes. During injury, gap junctions break apart. These broken channels undergo endocytosis, assemble into a double membrane structure termed a connexosome and then experience endosome sorting prior to transportation to lysosomes for degradation [53]. These events are paralleled by an upregulation of hemichannel activity and number, leading to an increase in release of molecules, including ATP, causing downstream inflammation and fibrosis via purinergic signalling. 


\section{Targeting Inflammation in Microvascular Complications of Diabetes}

Instrumental to the pathogenesis of diabetes and its complications, targeted antiinflammatory therapy has been suggested for both prevention and treatment of diabetes and has been extensively reviewed [54-56]. Known to underpin disease progression across multiple age associated conditions e.g., diabetes [55], obesity [25] and age-related macular degeneration [57], recent attention has focussed on the design of pharmacological compounds that block key inflammatory candidates, such as the nod-like receptor protein 3 (NLRP3) inflammasome (e.g., MCC950) [58], changes in cell phenotype (e.g., senolytics) [59] or cell function (e.g., sodium-glucose co-transporter-2 inhibitors: SGLT2i) [60-62].

The NLRP3 inflammasome has been referred to as the 'grumpy old man of inflammation' [63] and is linked to a variety of inflammatory conditions including atherosclerosis [64], Alzheimer's disease [27], inflammatory bowel disease [65], and non-alcoholic steatohepatitis [66]. It is upregulated in immune and epithelial cells across different tissue types, where activation culminates in secretion of pro-inflammatory mediators, interleukin-1 $\beta$ (IL1 $\beta$ ) and interleukin-18 (IL18). In turn, these activate tumour necrosis factor-alpha (TNF $\alpha$ ) and interleukin-6 (IL6), both of which exhibit increased serum levels with age and disease and mediate inflammation/fibrosis in multiple secondary complications of diabetes [67-71]. Since chronic inflammatory conditions are amplified and perpetuated by the inflammasome pathway, it is not surprising that blocking the NLRP3 inflammasome directly (e.g., MCC950) alleviates inflammation across multiple age-associated morbidities [60,68,72].

Despite these encouraging observations, blanket blockade of a complex integral part of the innate immune response has been met with concern. Activated by both damageassociated molecular patterns (DAMPs) and pathogen associated molecular patterns (PAMPs), the NLRP3 inflammasome mediates both sterile and non-sterile inflammation [73]. Consequently, whilst inhibition of NLRP3 inflammasome may protect against sterile inflammation induced by endogenous noxious stimuli, this could render individuals susceptible to injury where PAMP-associated microbial infection fails to elicit a response [74,75]. Nevertheless, with the NLRP3 having been identified as a key mediator of inflammation in over 80 different models of injury [76-80], it is not surprising that various compounds have entered clinical trials, e.g., Inzomelid (NCT04015076), IFM-2427 (DFV890) (NCT04382053) and Dapansutrile (OLT1177) (NCT04540120) [81]. Despite this, a drug which successfully targets NLRP3 is yet to reach its primary endpoint, an observation compounded by our lack of knowledge of its structure and potential binding sites [82]. Consequently, interventions to target downstream mediators e.g., IL1 $\beta$ and $\mathrm{TNF} \alpha$, have received considerable attention. Canakinumab (ACZ885, Ilaris) is a recombinant human monoclonal antibody that selectively inhibits IL1 $\beta$ receptor binding and demonstrated positive primary outcomes in the Canakinumab Anti-inflammatory Thrombosis Outcome Study (CANTOS) [83]. It subsequently became licensed for the treatment of rare inflammatory conditions, including juvenile arthritis [84]. However, its efficacy proved disappointing in the treatment of inflammation in diabetic retinopathy (NCT01589029), Type I Diabetes Mellitus (T1DM) (NCT00947427, [85]) and atherosclerosis (NCT00900146, [86]), an effect potentially linked to increased infection rates and sepsis [87]. Similar efforts to target TNF $\alpha$ include compounds that contain either receptor fusion proteins (etanercept) [88], which suppress the physiological response to $\mathrm{TNF} \alpha$, or monoclonal antibodies (golimumab, infliximab, adalimumab and certolizumab pegol), all of which have met mixed success [89].

Whilst evident that there is much to learn in our quest to develop new interventions that successfully (a) target sterile inflammation and (b) do so in the absence of serious side effects, recent FDA approval of SGLT2 inhibitors has perhaps been the most significant step forward in managing and improving outcomes in patients with nephropathy [90] and cardiovascular disease [91]. By blocking sodium glucose co-transport and reducing blood glucose levels, SGLT2i demonstrate improved renal and cardiovascular outcomes in patients with T2DM and diabetic nephropathy [92-94]. Whilst initial protection is thought to stem from a decrease in glomerular hyperfiltration, several studies demonstrate that SGLT2i confer protection via suppression of inflammation and fibrosis, albeit the 
widespread mechanisms remain to be fully elucidated [95-97]. However, with prescription targeted to individuals with T2DM as opposed to T1DM and potential side effects that include ketoacidosis [98], increased risk of amputation [99], and increased genitourinary tract infection [100], SGLT2i are not a one size fits all. As an alternative approach, Cx43 hemichannel blockers are a class of drugs which include Gap19 [101] and Tonabersat [102,103]. They bind to, and close hemichannels to prevent the release of numerous DAMPs, including ATP (for a more detailed review of how these peptides work we refer the reader to King et al. as published in this special issue) [104]. In the presence of DAMPs, the NLRP3 complex is activated and elicits an inappropriate inflammatory response, stimulating and activating via local paracrine mediated signalling, both infiltrating immune cells and resident fibroblasts $[50,78,105,106]$. On this basis alone, it is not hard to understand why connexin hemichannel blockers are increasingly championed as an effective therapeutic strategy in inhibition of sterile inflammation in disease.

\section{Cx43 Hemichannel Blockers and Treatment of Inflammation in Diabetes and Its Secondary Complications}

With evidence that $\mathrm{Cx} 43$ hemichannel mediated communication contributes to the pathogenesis and progression of tissue damage in secondary complications of diabetes [49,107,108], drugs that target $\mathrm{Cx} 43$ hemichannels have been identified as potential anti-inflammatory therapies $[109,110]$. Compounds of interest include Peptide 5, known to bind to the second extracellular loop of Cx43 [111]; Gap26, which mimics the first extracellular loop of Cx43 [112]; and $\alpha \mathrm{CT1}$, a Cx43-based peptide [113]. Their mechanism of action, along with models in which they have been trialled are summarised in Table 1. These compounds specifically inhibit Cx43 hemichannel opening [114] and have demonstrated efficacy in preventing the release of tissue damage inducing signals and thus alleviating downstream inflammation and fibrosis in secondary complications of diabetes [105], including diabetic nephropathy [108].

Table 1. Cx43 hemichannel blockers, mechanism of action and models in which they have been trialled to date.

\begin{tabular}{|c|c|c|c|c|}
\hline $\begin{array}{l}\text { Hemichannel } \\
\text { Blocker/ } \\
\text { Therapeutic Agent }\end{array}$ & $\begin{array}{l}\text { Sequence/ } \\
\text { Formula }\end{array}$ & Mechanism of Action & Examples of Models Trialled in & $\begin{array}{c}\text { Clinical } \\
\text { Trials? }\end{array}$ \\
\hline Gap19 & $\begin{array}{c}\text { KQIEIKKFK } \\
\text { Also: } \\
\text { Transactivator of } \\
\text { transcription } \\
\text { (TAT)-Gap19 } \\
\text {-YGRKKRRQRRR- } \\
\text { KQIEIKKFK } \\
\text { Xentry (XG19) } \\
\text {-lclrpvGG-KQIEIKKFK }\end{array}$ & $\begin{array}{l}\text { Binds to the intracellular } \\
\text { loop of Cx43, whilst not } \\
\text { affecting gap junction } \\
\text { communication [115]. } \\
\text { Exhibits low cell } \\
\text { permeability, so is often } \\
\text { coupled with TAT which } \\
\text { aids transcription or } \\
\text { Xentry which is a cell } \\
\text { penetrating } \\
\text { peptide [116]. }\end{array}$ & $\begin{array}{c}\text { Primary mouse } \\
\text { cardiomyocytes [117]; } \\
\text { Cerebral ischaemia/injury in } \\
\text { mice [118]; } \\
\text { Primary mouse } \\
\text { astrocytes/hippocampal slices } \\
\text { (TAT-Gap19) [115]; } \\
\text { Immortalised human retinal } \\
\text { pigment epithelium cells } \\
\text { (ARPE-19)/ primary human retinal } \\
\text { microvascular endothelial cells } \\
\text { (hREMC) (XG19) [116]; } \\
\text { Isolated rat hepatocytes [119]; } \\
\text { Human gingival fibroblasts [120]. }\end{array}$ & None found. \\
\hline Gap26 & VCYDKSFPISHVR & $\begin{array}{l}\text { Originally developed to } \\
\text { block gap junction } \\
\text { communication [121]. } \\
\text { Now shown to also block } \\
\text { hemichannels, Gap26 } \\
\text { binds to the first } \\
\text { extracellular loop of } \\
\text { Cx43 [112]. }\end{array}$ & $\begin{array}{c}\text { Isolated pig ventricular } \\
\text { cardiomyocytes [117]; } \\
\text { Cultured microglia, astrocytes and } \\
\text { neurons [122]. }\end{array}$ & None found. \\
\hline
\end{tabular}


Table 1. Cont.

\begin{tabular}{|c|c|c|}
\hline $\begin{array}{c}\text { Hemichannel } \\
\text { Blocker/ } \\
\text { Therapeutic Agent }\end{array}$ & $\begin{array}{l}\text { Sequence/ } \\
\text { Formula }\end{array}$ & Mechanism of Action \\
\hline Gap27 & SRPTEKTIFII & $\begin{array}{l}\text { Originally designed for } \\
\text { gap junction } \\
\text { blockade [121], Gap27 } \\
\text { can also block } \\
\text { hemichannels by binding } \\
\text { to the second } \\
\text { extracellular loop of } \\
\text { Cx43 [112]. }\end{array}$ \\
\hline
\end{tabular}

$\begin{array}{cc}\text { Examples of Models Trialled in } & \text { Clinical } \\ \text { Trials? }\end{array}$

Isolated pig ventricular cardiomyocytes [117];

Primary human corneal epithelial cells in vitro, human corneas ex vivo rat wound healing model in vivo [123];

None found.

Adult keratinocytes, juvenile foreskin, human neonatal fibroblasts and adult dermal tissue as models of wound healing [124].

Human primary proximal tubule epithelial cells and clonal tubular

kidney epithelial cells [108];

Retinal pigment epithelial cells $[105,125]$;

None found extracellular loop of Cx43, preventing hemichannel opening [111].
Patch-clamp inflammatory model in mice [102];

Light-damaged albino rat model [126].

\begin{tabular}{cc}
\hline & $\begin{array}{c}\text { Able to block gap } \\
\text { junctions (at high } \\
\text { Tonabersat (Xiflam) }\end{array} \quad \mathrm{C}_{20} \mathrm{H}_{19} \mathrm{ClFNO}_{4} \quad \begin{array}{c}\text { concentration), this small } \\
\text { molecule, a benzopyran } \\
\text { derivative can block } \\
\text { Cx43 hemichannels at } \\
\text { lower doses [50]. }\end{array}$ \\
\hline
\end{tabular}

Human retinal pigment epithelial cells (ARPE-19) [50]; Rat model of diabetic retinopathy [127].

Phase II

clinical trials

in migraines-

NCT00311662

NCT00534560

NCT00332007

Clinical trials for diabetic

foot ulcers as

'Grannexin gel'

Phase I(cytoplasmic terminus) of Cx43 [113], mediating

alpha connexin carboxyl terminus 1 $(\alpha \mathrm{CT} 1)$
Ant-RPRPDDLEI phosphorylation of Cx43 at serine 368 [128]. Has also been shown to affect gap junction remodelling [129].
Rat model corneal wound [130];

Beneficial in a randomised control trial assessing cutaneous scarring [131];

Human biopsy tissue/rat and guinea pig scars [132].
NCT02652754

Phase II-

NCT02652572

Terminated at phase III May 2020

(NCT02667327)no safety concerns
Primary human proximal tubule epithelial cells [135];

Rat Retinal Endothelial cells during high glucose stress [134]; Myocardial infarct in pigs [136] and dogs [137];

Atrial fibrillation models in dogs [138,139].
Phase II for myocardial infarction-

NCT01977755
Danegaptide
(GAP-134) $\quad \mathrm{C}_{14} \mathrm{H}_{17} \mathrm{~N}_{3} \mathrm{O}_{4}$ been shown to block Cx43 hemichannels in human proximal tubule epithelial cells [135].

\section{Cx43 Hemichannels and Treatment of Inflammation in Diabetic Kidney Disease}

Diabetic nephropathy is widely regarded as a glomerular disease, where proteinuria is the predominant early clinical marker [140]. Signs of glomerular injury include podocyte 
damage and effacement [141,142], crescent formation [143], basement membrane thickening [144], macrophage infiltration [145] and inflammation [146]. Early studies evaluating a link between connexins and glomerular damage observed increased Cx43 expression in both biopsies from injured human glomeruli and in the nephrotoxic glomerulonephritis (NTS-GN) murine model of chronic kidney disease [147]. The NTS-GN models exhibits a similar presentation to the streptozotocin (STZ) mouse model of T1DM, with histological and functional studies reporting that these mice develop glomerulosclerosis, inflammation, fibrosis, and albuminuria [148]. In NTS-GN mice, up-regulation of Cx43 occurs via increased binding of activated protein-1 (AP-1) transcription factors, phosphorylated (p)cellular (c) JUN, p-signal transducer, and activator of transcription-1 (STAT1) to the Cx43 promoter [147]. Furthermore, in mice treated with a Cx43 specific antisense oligodeoxynucleotide or in the heterogenous $\mathrm{C} \times 43^{+/-}$mouse induced with NTS-GN, proteinuria, blood urea nitrogen (BUN) and serum creatinine levels are reduced [148]. Similar observations were also reported in the STZ-induced rat when treated with Cx43 small interfering ribonucleic acid (siRNA) [149]. This protection may stem from impaired autophagy, an intracellular degradation mechanism which removes/recycles dysfunctional or unnecessary cellular components to ensure efficient health and function of the cell [149]. Mediated through activation of mammalian target of rapamycin (mTOR) signalling, high glucose treated mouse podocytes (MPC5) in which Cx43 expression was reduced via transient transfection with siRNA, exhibit reduced mTOR activation, impaired autophagic flux and decreased podocyte injury [149]. Paracrine mediated purinergic signalling has also been linked to Cx43 induced podocyte injury, with transforming growth factor beta 1 (TGF $\beta 1$ ) treated mouse E.11 podocytes, co-incubated with Cx43 specific blocking peptide Gap26 and purinergic receptor blocker suramin, exhibiting attenuated cytoskeletal reorganisation, improved morphology and a decrease in apoptosis compared to TGF $\beta 1$ alone [147].

Although a glomerular disease in origin, advanced stages of nephropathy are characterised by severe tubule interstitial inflammation and fibrosis [150]. Work within our laboratories links altered Cx43 expression to tubule injury in both in vitro $[108,135,151,152]$ and in vivo [108] models of disease [153]. Initial observations identified an approximate 5-fold increase in Cx43 expression in biopsy material from individuals with diabetic nephropathy compared to healthy control [151], whilst paired-patch electrophysiology and ATP biosensing suggested that this increased expression was paralleled by diminished gap-junction intercellular coupling (GJIC) and increased hemichannel mediated ATP release [151]. With intercellular adhesion a pre-requisite for gap junction formation, AFM-single cell force spectroscopy [154] determined that this loss of direct cell coupling paralleled the reduction of E-Cadherin mediated cell adhesion [155], an effect significantly blunted by co-incubation with the P2X7 receptor (P2X7R) antagonists Suramin, A438079 or A804598 [108,156]. Previous studies link P2X7R activation to macrophage and extracellular matrix deposition in both in vitro models of diabetic kidney disease [108,157] and in STZ-induced diabetic mice [157], whilst we recently observed increased P2X7R expression in renal biopsy from people with diabetic nephropathy and in the unilateral ureteral obstruction (UUO) mouse model [108]. The UUO is a model of advanced interstitial inflammation and fibrosis which recapitulates late-stage damage observed in the diabetic kidney, irrespective of the initiating stimuli [158]. It is widely used for mechanistic studies in all forms of advanced CKD [158]. Despite our knowledge of a role for P2X7R activation in disease pathogenesis, attempts to target P2X7 have been relatively unsuccessful, potentially due to the genetic variability of the human P2X7 receptor which can lead to altered pharmacodynamic responses $[159,160]$. Consequently, having identified that impaired gap junction coupling is paralleled by increased hemichannel mediated ATP release [151], combined with evidence that elevated ATP and sustained P2X7R are linked to onset and progression of inflammation and fibrosis in multiple tissue types, we assessed a role for both Cx43 and P2X7R activation in disassembly of the adherens and tight junction complex in both TGF $\beta 1$ treated human primary tubule cells co-incubated with P2X7R inhibitors A438079 and A804598 and in the $\mathrm{C}_{433^{+/}}$UUO mouse model [108]. Blocking the P2X7R significantly blunted the 
TGF $\beta 1$ evoked change in adherens (E-Cadherin, N-Cadherin) and tight junction proteins (Claudin-2 and Zona Occludins (ZO-1)), whilst restoring both cell adhesion and paracellular permeability [107]. Not surprisingly, these TGF $\beta 1$-induced effects were significantly diminished when cells were co-incubated with Apyrase, an ATP-diphosphohydrolase that catalyses the sequential hydrolysis of ATP to ADP, then AMP and adenosine, suggesting a downstream role for ATP in mediating the actions of TGF $\beta 1$. The origin of this signal is further supported by our recent studies in the $\mathrm{C} \times 43^{+/-}$UUO mouse where disassembly of the adherens (e.g., E-cadherin) and tight (e.g., ZO-1) junction complexes were significantly blunted as compared to wild-type control [108]. Whilst collectively these studies support a role for $\mathrm{Cx} 43$ and downstream purinergic signaling in tubular injury, understanding how this protection is conferred is instrumental if wanting to target this communication through pharmacological intervention.

In contrast to the observations above, Sun et al. recently suggested that $\mathrm{Cx} 43$ expression is downregulated in diabetic kidney disease and that overexpression of Cx43 using short hairpin RNAs attenuates renal fibrosis and reduces epithelial-to-mesenchymal transition (EMT) in a carboxyl-terminal signal transduction-dependent manner in leptin receptor-deficient type 2 diabetic $(\mathrm{db} / \mathrm{db})$ mice and in rat kidney NRK-52E cells treated with high $(30 \mathrm{mM})$ glucose [161]. They attributed this non-channel dependent effect to regulation of the sirtuin-1 hypoxia inducible factor-1alpha (SIRT1-HIF-1a) signalling pathway and have more recently suggested that the protective effects of $\mathrm{Cx} 43$ are associated with ubiquitin-specific protease 9X (USP9X/FAM) mediated de-ubiquitination [161]. Whilst the implications of this altered Cx43 expression for cell communication remains to be reported in these models, combined evidence from other studies suggest that blocking Cx43 hemichannels through mimetic peptides may represent a novel approach in targeting inflammation and fibrosis in multiple tissue types [108,113,162,163].

Peptide 5 is a connexin peptidomimetic that mimics a portion of the 2nd extracellular loop of Cx43 [111] and has proven effective in blocking Cx43 hemichannels and preventing ATP release in multiple models of injury when delivered intraocularly [126], into cerebrospinal fluid [164] and systemically [165]. Studies confirm target applicability and specificity and yield similar and significant benefits across different injury models $[108,126,164-166]$. Our recent findings determined that elevated levels of TGF $\beta 1$ increase Cx43 hemichannel mediated ATP release [151], an effect which drives P2X7R mediated phenotypic changes linked to initiation of partial EMT in the proximal region of the kidney $[108,164]$. Co-incubation of TGF $\beta 1$ treated human proximal tubule epithelial cells (hPTECs) with Peptide 5, successfully blocked hemichannel mediated carboxyfluorescein dye uptake and real time ATP release, the impact of which was evidenced by restoration of expression of adherens and tight junction proteins in injured cells [108].

Instrumental to cell adhesion and maintenance of polarity, disassembly of cell junction complexes is linked to partial EMT, events which predispose inflammation and fibrosis [167], the latter of which is contributed to by extracellular matrix (ECM) deposition [152]. With collagen I increased in the interstitium of UUO mice, an effect lessened in the $\mathrm{Cx} 43^{+/-}$ model [168], we hypothesized that a modified microenvironment may elicit phenotypic changes via increased Cx43 mediated hemichannel ATP release. Consequently, we observed that TGF $\beta 1$ treated human kidney cells bond with increased affinity to collagen I via integrin isoform $\alpha 2 \beta 1$, an interaction which shifted the cell phenotype to one of increased expression of integrin linked kinase, $\mathrm{N}$-cadherin, fibronectin and collagen IV as compared to cells uncoated control. Interestingly, co-incubation of TGF $\beta 1$ treated cells with Peptide 5 significantly blocked the increase in hemichannel mediated dye uptake and ultimately restored expression of markers of tubular injury to levels representative of control cells cultured on plastic. Moreover, Peptide 5 blocked TGF $\beta 1$ induced secretion of collagen I [168], corroborating in vivo data in the $\mathrm{C} \times 43^{+/-}$mouse [168] and highlighting the existence of a potential feedback loop in which aberrant Cx43 hemichannel mediated ATP release increases collagen I secretion and deposition, the latter of which perpetuates tubular injury via a Cx43 hemichannel mediated mechanism. 
Building on our published observations with Peptide 5, we recently assessed the efficacy of Danegaptide in conferring protection in an in vitro model of tubular injury. A Cx43 gap junction modifier $[133,134]$, we reported that Danegaptide was also able to block hemichannel mediated dye uptake, ATP release and consequently TGF $\beta 1$ induced changes in markers of tubular injury e.g., E-Cadherin and N-Cadherin and fibrosis e.g., collagenI, collagen-IV and fibronectin in human primary tubule epithelial cells (hPTECs) [135]. Furthermore, based on evidence that the $\mathrm{C} \times 43^{+/-}$UUO mouse presents with decreased fibroblast activation and diminished macrophage infiltration as compared to wild type UUO control [168], we employed proteome profiler arrays to screen for the expression profile of 125 inflammatory cytokines in TGF $\beta 1$ treated human primary proximal tubule cells in the presence/absence of Danegaptide [135]. Soluble chemokines, adhesion molecules and growth factors recruit and activate infiltrating immune cells and resident fibroblasts to mediate inflammation and fibrosis in the diabetic kidney [135]. However, little is known about the switch that triggers release of these chemotactic signals or whether blocking this switch has implications for heterotypic cell communication. Whilst we are yet to fully understand the role of $\mathrm{C} \times 43$ hemichannel activity in these paracrine mediated events, we observed that Danegaptide significantly blocked Cx43-mediated ATP release in tubular epithelial cells to negate secretion of many inflammatory mediators, including chemokines, monocyte chemoattractant protein (MCP1), Regulated upon Activation, Normal T Cells Expressed and presumably Secreted (RANTES; involved in macrophage infiltration $[169,170]$ ), inflammatory interleukins (IL6 and IL1 $\beta$ ) and adipokine adiponectin (associated with macrophage-to-myofibroblast differentiation [171]). In support of our in vitro data and $\mathrm{C} 43^{+/-}$UUO mouse [108], work by Abed et al. demonstrated that the number of primary monocytes which adhere to an activated mouse endothelial cell monolayer is reduced in endothelial cells co-incubated with Gap26 [168]. The findings highlight the tantalising therapeutic potential of targeting Cx43 hemichannel activity in diabetic nephropathy and other forms of CKD. It remains to be resolved how blocking Cx43 confers protection in vivo, whilst further research is required to assess the efficacy of $\mathrm{Cx} 43$ mimetic peptides in a clinical setting.

\section{The Therapeutic Potential of Blocking Cx43 in Diabetic Retinopathy}

Diabetic retinopathy affects around one third of people with diabetes and is the primary contributor to blindness in the working age population [172], often resulting in sight loss as a consequence of diabetic macular oedema, haemorrhage or retinal detachment [173]. This is due to increased cell apoptosis, vascular permeability and disruption of retinal homeostasis [173]. Categorised into two clinical stages of disease, diabetic retinopathy initially presents as a non-proliferative form, characterised by inflammation, hypertrophy, oedema, capillary breakdown, ischemia, and loss of microvascular endothelium integrity leading to abnormal blood-retinal barrier (BRB) permeability [9]. The subsequent decrease in blood flow and nutrient supply drives progression to the proliferative stage where increased blood vessel formation leads to haemorrhage and scar tissue formation [9]. These pathologies can cause detachment of the retina resulting in severe or complete blindness [9].

Loss of vision in retinopathy is associated with breakdown of the retinal pigment epithelium (RPE), where periods of sustained hyperglycemia drive inflammation and apoptosis through increased secretion of key inflammatory mediators, growth factors and hypoxia-inducible factors [174]. This inflammation is believed to actively contribute to associated damage of the retinal vasculature through its ability to trigger apoptosis of RPE cells and promotion of retinal neovascularization. Of the main damage inducing molecules whose activity and expression is known to be upregulated in the diabetic eye, it is the increased secretion of vascular endothelial growth factor (VEGF) which triggers neovascularisation and onset of the proliferative stage of diabetic retinopathy [175]. Coupled with the breakdown of tight junctions between cells of the RPE, disruption to the retinal pigment epithelium allows for these newly developed and fragile blood vessels to push through and leak into the macula. The resulting macular oedema is one of the greatest 
contributors to sight loss in diabetic retinopathy [176]. Whilst laser treatments [177] and anti-VEGF injections [178] stabilise blood vessels and prevent further neovascularisation respectively, targeting upstream of this RPE breakdown and inflammation is a major focus in the field. Tackling the condition in its early stages, and thus preventing transition of the non-proliferative to proliferative stage, will not only improve patient outcomes but reduce the socioeconomic burden of this disease.

In targeting this damage, it is important to understand how it manifests itself. Interestingly, the series of events which drive proliferative diabetic retinopathy are of a similar aetiology to those which we see in late-stage diabetic kidney disease [23]. As with onset and progression of tubulointerstitial fibrosis [167], the breakdown of the retinal pigment epithelium is associated with disassembly of junction proteins, namely ZO-1, E-cadherin, $\beta$-catenin and occludin and ultimately induction of EMT [179]. In fact, EMT of RPE cells is considered an initiating trigger in the loss of epithelial integrity and is driven by glucoseevoked changes in TGF $\beta$ [180]. Moreover, a recent study by Lyon et al. identified that inflammation coupled with glycaemic damage mediates EMT of the RPE via aberrant Cx43 mediated hemichannel activity [50], whilst Peptide 5 blocked loss of ZO-1 expression and restores RPE permeability as measured by transepithelial resistance [125]. These studies further support the extensive work in the field of connexin biology and ophthalmology, which in recent years has identified a key pathological role for connexin hemichannels in ophthalmological disease [47].

Both in vitro [105] and in vivo [181] models of diabetic retinopathy have been used to evaluate a role for $\mathrm{C} \times 43$ mediated communication when treated with IL1ß and TNF $\alpha$ in the presence of high glucose. Using clonal human retinal pigment epithelial cells (ARPE-19) and NOD mice, Mugisho et al. demonstrated that these cells exhibit increased expression of $\mathrm{Cx} 43$, an effect exacerbated in the presence of both glucose and inflammation. This increased Cx43 expression was paralleled by enhanced secretion of pro-inflammatory cytokines (interleukin-6, interleukin-18, monocyte chemoattractant protein-1, and intercellular adhesion molecule 1), angiogenic promoting VEGF [181] and downstream extracellular matrix protein collagen-IV [125]. Furthermore, with evidence that these cells release elevated levels of ATP, the authors subsequently determined that these effects were blunted in the presence of Cx43 hemichannel blocker Peptide 5, whilst exogenous application of ATP and restoration of the response further corroborated a role for $\mathrm{Cx} 43$ in driving these in vitro observations [105,125]. In vivo Cx43 expression increased in both the Akimba (albeit not the Akita) mouse, whilst increased expression was also observed in donor retinas with confirmed diabetic retinopathy compared to age-matched controls [182]. In addition, and building on their in vitro observations, the team developed an in vivo model of diabetic retinopathy in which pro-inflammatory cytokines, IL1 $\beta$ and TNF $\alpha$, were injected into the vitreous of NOD mice. Results showed that injecting intravitreal cytokines into these mice induced a host of parameters detrimental to tissue function, including severe vitreous hyper-reflective foci, vessel dilation, oedema microglia upregulation [183]. With previous evidence that Peptide 5 was able to prevent Cx43 mediated vascular leakage and retinal ganglion cell death after retinal ischaemic injury in rats [159], Peptide 5 was administered to these NOD mice and structural and functional parameters recorded. Injection of Peptide 5 significantly improved vessel dilation and beading, reduced sub-retinal fluid accumulation, decreased microglial infiltration into the outer nuclear layer, and decreased expression of both NLRP3 and the adaptor protein ASC, the latter of which suggests a link between Cx43 hemichannels and activation of the inflammasome pathway [182].

Since the NLRP3 inflammasome is an integral mediator of our innate immune response, the link between aberrant $\mathrm{Cx} 43$ hemichannel mediated ATP release and activation of the NLRP3 inflammasome was further explored in vitro, where NLRP3 complex assembly, caspase 1 activation and IL1 $\beta$ secretion were blocked in treated ARPE-19 cells co-incubated with Peptide 5 [105]. Similarly, Cx43 hemichannel blocker, Tonabersat (Xiflam) also protected against retinal injury by blocking Cx43 mediated ATP release, NLRP3 inflammasome activation and the release of pro-inflammatory mediators e.g., IL1 $\beta$, IL6 and VEGF, in both 
high treated ARPE-19 cells [50] and in organotypic human retinal explants [184]. Blockade of the NLRP3 inflammasome in addition to those events described above dampened the immune response, reduced aneurysm development and restored cell function. In the light damaged albino rat model of diabetic retinopathy when treated with either Peptide 5 [126] or Tonabersat [185] the resultant changes in photoreceptor function and vascular permeability observed were accompanied by a reduced rate of disease progression [185].

Whilst the evidence of a role for Cx43 hemichannels in driving the pathology of diabetic retinopathy is undeniable, loss of tissue function in response to altered GJIC has also been reported. Under conditions of glycaemic injury, Cx43 gap junction coupling is reduced in retinal capillaries from people with diabetes [185,186], rat microvascular endothelial cells [187] and in pericytes [188]. Implications for these changes were associated with endothelial cell apoptosis [187], pericyte death [186,188] and acellular capillary formation [187]. With evidence that Danegaptide confers protection in in vitro models of diabetic nephropathy and diabetic retinopathy $[135,188]$, the dipeptide has specifically been shown to maintain gap junction coupling between endothelial cells despite high glucose stress, as assessed using scrape load dye transfer. In primary rat retinal endothelial cells, Danegaptide modulated a high glucose induced increase in apoptosis and cell permeability [188], thus further highlighting the promising effects in regulating Cx43 mediated communication via modulation of their activity with mimetic peptides.

\section{Conclusions}

Recent statistics from Eurostat suggest that $28 \%$ of Europeans will be aged $65 \mathrm{yr}$ and older by 2060, with estimates predicting the average UK life expectancy of women to be $91 \mathrm{yr}$ and men $88 \mathrm{yr}$ by 2030 [134]. With the prevalence of T2DM linked exponentially to the aging process the incidence of diabetes and its secondary complications is expected to rise. Chronic inflammation is a hallmark of retinopathy [189] and nephropathy [190,191], with induction of morphological and phenotypic cell changes linked to upstream activation of the NLRP3 inflammasome [192-199]. In a bid to target chronic inflammation, the recent field of senolytics and NLRP3 inhibitors have taken centre stage $[59,67]$. However, although promising (e.g., Dasatanib \& Quercertin [200]), more information about safety, tolerability and off-target effects of these drugs is required. In addition, targeting the NLRP3 inflammasome (e.g., MCC950 [200]) or downstream IL1 $\beta$ (e.g., Canakinumab [87,200]) has raised concerns over increased susceptibility to pathogenic infection and long-term side effects. Consequently, treatment of inflammation in progressive nephropathy and retinopathy remains an unmet need. Connexin hemichannel blockers represent a promising future therapeutic option in the treatment of nephropathy and retinopathy. Research to date is persuasive and highlights promising beneficial effects of Cx43 inhibition on inflammation, tissue integrity and fibrosis $[180,201,202]$. However, the field requires further research to determine the effectiveness and efficacy of drugs and the long-term benefits.

Author Contributions: Conceptualization, C.L.C., B.M.W., C.E.C., U.M., P.E.S.; writing-original draft preparation, C.L.C., B.M.W., P.E.S. and C.E.H.; writing-review C.L.C., B.M.W., C.E.C., U.M., P.E.S. and C.E.H.; Supervision, C.E.H. and P.E.S., project administration, P.E.S. and C.E.H. All authors have read and agreed to the published version of the manuscript.

Funding: This research was funded by the generous support of Diabetes UK (18/0005919).

Conflicts of Interest: C.L.C., B.M.W., C.E.C., P.E.S. and C.E.H. declare no conflict of interest. U.M. has equity ownership in and is an employee of Ciana Therapeutics, which is developing products related to the research being reported. The terms of this arrangement have been reviewed and approved by the University of Lincoln in accordance with its policy on objectivity in research.

\section{References}

1. International Diabetes Federation, Ninth Edition. 2019. Available online: https://www.diabetesatlas.org/upload/resources/ material/20200302_133351_IDFATLAS9e-final-web.pdf (accessed on 23 November 2021).

2. Whicher, C.A.; O'Neill, S.; Holt, R.I.G. Diabetes in the UK: 2019. Diabet. Med. 2020, 37, 242-247. [CrossRef] 
3. Einarson, T.R.; Acs, A.; Ludwig, C.; Panton, U.H. Prevalence of cardiovascular disease in type 2 diabetes: A systematic literature review of scientific evidence from across the world in 2007-2017. Cardiovac. Diabetol. 2018, 17, 1-19. [CrossRef]

4. Soyoye, D.O.; Ablodun, O.O.; Ikem, R.T.; Kolawole, B.A.; Akintomide, A.O. Diabetes and peripheral artery disease: A review. World J. Diabetes 2021, 12, 827-838. [CrossRef]

5. Huang, D.; Refaat, M.; Mohammedi, K.; Jayyousi, A.; Suwaidi, J.A.; Khalil, C.A. Biomed. Res. Int. 2017, 2017, 1-9. [CrossRef]

6. Chen, Y.; Lee, K.; Ni, Z.; He, J.C. Diabetic kidney disease: Challenges, advances, and opportunities. Kidney Dis. 2020, 6, 215-225. [CrossRef] [PubMed]

7. $\quad$ Keshari, K.R.; Wilson, D.M.; Sai, V.; Bok, R.; Jen, K.; Larson, P.; van Criekinge, M.; Kurhanewicz, J.; Wang, Z.J. Noninvasive in vivo imaging of diabetes-induced renal oxidative stress and response to therapy using hyperpolarized ${ }^{13} \mathrm{C}$ dehydroascorbate magnetic resonance. Am. Diabetes Assoc. 2015, 64, 344-352. [CrossRef] [PubMed]

8. Zoja, C.; Xinaris, C.; Macconi, D. Diabetic nephropathy: Novel molecular mechanisms and therapeutic targets. Front. Pharmacol. 2020, 11, 2139. [CrossRef] [PubMed]

9. Wang, W.; Lo, A.C.Y. Diabetic retinopathy: Pathophysiology and treatments. Int. J. Mol. Sci. 2018, 19, 1816. [CrossRef]

10. Sabanayagam, C.; Banu, R.; Chee, M.L.; Lee, R.; Wang, Y.X.; Tan, G.T.; Jonas, J.B.; Lamourex, E.L.; Cheng, C.Y.; Klein, B.E.K.; et al. Incidence and progression of diabetic retinopathy: A systematic review. Lancet 2019, 7, 140-149. [CrossRef]

11. Lan, C.C.E.; Wu, C.S.; Huang, S.M.; Wu, I.H.; Chen, G.S. High-glucose environment enhanced oxidative stress and interleukin-8 secretion from keratinocytes: New insights into impaired diabetic wound healing. Am. Diabetes Assoc. 2013, 62, $2530-2538$. [CrossRef] [PubMed]

12. Spampinato, S.F.; Caruso, G.I.; de Pasquale, R.; Sortino, M.A.; Merlo, S. The treatment of impaired wound healing in diabetes: Looking among old drugs. Pharmaceuticals 2020, 13, 60. [CrossRef]

13. MacIsaac, R.J.; Jerums, G.; Ekinci, E.I. Effects of glycaemic management on diabetic kidney disease. World J. Diabetes 2017, 8, 172-186. [CrossRef] [PubMed]

14. Hill-Briggs, F.; Adler, N.E.; Berkowitz, S.A.; Chin, M.H.; Gary-Webb, T.L.; Navas-Acien, A.; Thornton, P.L.; Haire-Joshu, D. Social determinants of health and diabetes: A scientific review. Diabetes Care 2021, 44, 258-279. [CrossRef] [PubMed]

15. Kim, J.; Nam, J.H. Insight into the relationship between obesity-induced low-level chronic inflammation and COVID-19 infection. Int. J. Obes. 2020, 44, 1541-1542. [CrossRef] [PubMed]

16. Catalán, V.; Gómez-Ambrosi, J.; Ramirez, B.; Rotellar, F.; Pastor, C.; Silva, C.; Rodríguez, A.; Gil, M.J.; Cienfuegos, F.A.; Frühbeck, G. Proinflammatory cytokines in obesity: Impact of type 2 diabetes mellitus and gastric bypass. Obes. Surg. 2007, 17, 1464-1474. [CrossRef]

17. Muniz, M.G.R.; Palfreeman, M.; Setzu, N.; Sanchez, M.A.; Portillo, P.S.; Garza, K.M.; Gosselink, K.L.; Spencer, C.T. Obesity exacerbates the cytokine storm elicited by Francisella tularensis infection of females and is associated with increased mortality. Adv. Emerg. Negl. Infect. Dis. 2018, 2018, 1-9. [CrossRef]

18. Vandanmagsar, B.; Youm, Y.H.; Ravussin, A.; Galgani, J.E.; Stadler, K.; Mynatt, R.L.; Ravussin, E.; Stephens, J.M.; Dixit, V.D. The NLRP3 inflammasome instigates obesity-induced inflammation and insulin resistance. Nat. Med. 2011, 17, 179-188. [CrossRef]

19. Edwards, M.S.; Wilson, D.B.; Craven, T.E.; Stafford, J.; Fried, L.F.; Wong, T.Y.; Klein, R.; Burke, G.L.; Hansen, K.J. Associations between retinal microvascular abnormalities and declining renal function in the elderly population: The cardiovascular health study. Am. J. Kidney Dis. 2005, 2, 214-224. [CrossRef]

20. Jeng, C.J.; Hsieh, Y.T.; Yang, C.M.; Yang, C.H.; Lin, C.L.; Wang, I.J. Diabetic retinopathy in patients with diabetic nephropathy: Development and progression. PLoS ONE 2016, 11, e0161897. [CrossRef]

21. Park, Y.H.; Shin, J.A.; Han, J.H.; Park, Y.M.; Yim, H.W. The association between chronic kidney disease and diabetic retinopathy: The Korea national health and nutrition examination survey 2008-2010. PLoS ONE 2015, 10, e125338. [CrossRef]

22. Pedro, R.A.; Ramon, S.A.; Marc, B.B.; Juan, F.B.; Isabel, M.M. Prevalence and relationship between diabetic retinopathy and nephropathy, and its risk factors in the north-east of Spain, a population-based study. Ophthalmic Epidemiol. 2010, 17, 251-265. [CrossRef] [PubMed]

23. Zhang, J.; Wang, Y.; Li, L.; Zhang, R.; Guo, R.; Li, H.; Han, Q.; Teng, G.; Liu, F. Diabetic retinopathy may predict the renal outcomes of patients with diabetic nephropathy. Ren. Fail. 2018, 40, 243-251. [CrossRef]

24. Sasaki, T.; Numano, R.; Yokota-Hasimoto, H.; Matsui, S.; Kimura, N.; Takeuchi, H.; Kitamura, T. A central-acting connexin inhibitor, INI-0602, prevents high-fat diet-induced feeding pattern disturbances and obesity in mice. Mol. Brain 2018, 11, 28. [CrossRef] [PubMed]

25. Cañadas-Lozano, D.; Marín-Aguilar, F.; Castejón-Vega, B.; Ryffel, B.; Navarro-Pando, J.M.; Ruiz-Cabello, J.; Alcocer-Gómez, E.; Bullón, P.; Codero, M.D. Blockade of the NLRP3 inflammasome improves metabolic health and lifespan in obese mice. Geroscience 2020, 42, 715-725. [CrossRef]

26. Yi, C.; Ezan, P.; Fernández, P.; Schmitt, J.; Sáez, J.C.; Giaume, C.; Koulakoff, A. Inhibition of glial hemichannels by boldine treatment reduces neuronal suffering in a murine model of Alzheimer's disease. Glia 2017, 65, 1607-1625. [CrossRef] [PubMed]

27. Lonnemann, N.; Hosseini, S.; Marchetti, C.; Skouras, D.B.; Stefanoni, D.; D'Alessandro, A.; Dinarello, C.A.; Korte, M. The NLRP3 inflammasome inhibitor OLT1177 rescues cognitive impairment in a mouse model of Alzheimer's disease. Proc. Natl. Acad. Sci. USA 2020, 117, 32145-32154. [CrossRef] 
28. Carpintero-Fernández, P.; Sánchez, T.A.; Varela, E.M.; García-Yuste, A.; Yáñez, C.J.; Díez-Ulloa, A.; Caeiro, J.R.; Mayan, M.D. Connexin 43 and cellular senescence: New therapeutic strategies for treating osteoarthritis. Rev. Osteoporos. Metab. Miner. 2020, 12, 152-154. [CrossRef]

29. Wagner, C. Function of connexins in the renal circulation. Kidney Int. 2008, 73, 547-555. [CrossRef]

30. Fiori, M.C.; Reuss, L.; Cuello, L.G.; Altenberg, G.A. Functional analysis and regulation of purified connexin hemichannels. Front. Physiol. 2014, 5, 71. [CrossRef]

31. Beyer, E.C.; Berthoud, V.M. Gap junction structure: Unraveled, but not fully revealed. F1000Research 2017, 6, 568. [CrossRef]

32. Evans, W.H.; Ahmad, S.; Diez, J.; George, C.H.; Kendall, J.M.; Martin, P.E. Trafficking pathways leading to the formation of gap junctions. Novartis Found. Symp. 1999, 219, 244-254. [CrossRef]

33. Laird, D.W. Life cycle of connexins in health and disease. Biochem. J. 2006, 394, 527-543. [CrossRef]

34. Dong, A.; Liu, S.; Li, Y. Gap junctions in the nervous system: Probing functional connections using new imaging approaches. Front. Cell. Neurosci. 2018, 12, 320. [CrossRef]

35. Retamal, M.A.; Reyes, E.P.; García, I.E.; Pinto, B.; Martínez, A.D.; González, C. Diseases associated with leaky hemichannels. Front. Cell. Neurosci. 2015, 9, 267. [CrossRef]

36. Ribeiro-Rodrigues, T.M.; Martins-Marques, T.; Morel, S.; Kwak, B.R.; Girão, H. Role of connexin 43 in different forms of intercellular communication-Gap junctions, extracellular vesicles and tunnelling nanotubes. J. Cell Sci. 2017, 130, 3619-3630. [CrossRef] [PubMed]

37. Retamal, M.A.; Schalper, K.A.; Shoji, K.F.; Bennett, M.V.L.; Sáez, J.C. Opening of connexin 43 hemichannels is increased by lowering intracellular redox potential. Proc. Natl. Acad. Sci. USA 2007, 104, 8322-8327. [CrossRef] [PubMed]

38. Willebrords, J.; Yanguas, S.C.; Maes, M.; Decrock, E.; Wang, N.; Leybaert, L.; Kwak, B.R.; Green, C.R.; Cogliati, B.; Vinken, M. Connexins and their channels in inflammation. Crit. Rev. Biochem. Mol. Biol. 2016, 51, 413-439. [CrossRef] [PubMed]

39. Verselis, V.K. Connexin hemichannels and cochlear function. Neurosci. Lett. 2019, 695, 40-45. [CrossRef]

40. Ma, D.; Feng, L.; Cheng, Y.; Xin, M.; You, J.; Yin, X.; Hao, Y.; Cui, L.; Feng, J. Astrocytic gap junction inhibition by carbenoxolone enhances the protective effects of ischemic preconditioning following cerebral ischemia. J. Neuroinflamm. 2018, 15, 1-12. [CrossRef]

41. Yang, H.; Yan, H.; Li, X.; Liu, J.; Cao, S.; Huang, B.; Huang, D.; Wu, L. Inhibition of Connexin 43 and phosphorylated NR2B in spinal astrocytes attenuates bone cancer pain in mice. Front. Cell. Neurosci. 2018, 12, 129. [CrossRef]

42. Wang, H.; Sun, X. Carbon monoxide-releasing molecule-2 inhibits Connexin 43-hemichannel activity in spinal cord astrocytes to attenuate neuropathic pain. J. Mol. Neurosci. 2017, 63, 58-69. [CrossRef] [PubMed]

43. Zhang, Q.; Wu, S.; Sun, G.; Zhang, R.; Li, X.; Zhang, Y.; Huang, F.; Yuan, D. Hyperglycemia aggravates monocyte-endothelial adhesion in human umbilical vein endothelial cells from women with gestational diabetes mellitus by inducing Cx43 overexpression. Ann. Transl. Med. 2021, 9, 234. [CrossRef] [PubMed]

44. Tien, T.; Barrette, K.F.; Chronopoulos, A.; Roy, S. Effects of high glucose-induced Cx43 downregulation on occluding and ZO-1 expression and tight junction barrier function in retinal endothelial cells. Invest. Ophthalmol. Vis. Sci. 2013, 54, 6518-6525. [CrossRef] [PubMed]

45. Kim, D.; Lewis, C.; Sarthy, V.; Roy, S. High-glucose-induced rab20 upregulation disrupts gap junction intercellular communication and promotes apoptosis in retinal endothelial and müller cells: Implications for diabetic retinopathy. J. Clin. Med. 2020, 9, 3710. [CrossRef] [PubMed]

46. Sáez, J.; Contreras-Duarte, S.; Gómez, G.; Labra, V.C.; Santibañez, C.A.; Gajardo-Gómez, R.; Avendaño, B.C.; Díaz, E.F.; Montero, T.D.; Velarde, V. Connexin 43 hemichannel activity promoted by pro-inflammatory cytokines and high glucose alters endothelial cell function. Front. Immunol. 2018, 9, 1899. [CrossRef]

47. González-Casanova, J.; Schmachtenberg, O.; Martínez, A.D.; Sanchez, H.A.; Harcha, P.A.; Rojas-Gomez, D. An update on connexin gap junction and hemichannels in diabetic retinopathy. Int. J. Mol. Sci. 2021, 22, 3194. [CrossRef]

48. Sáez, J.C.; Contreras-Duarte, S.; Labra, V.C.; Santibañez, C.A.; Mellado, L.A.; Inostroza, C.A.; Alvear, T.F.; Retamal, M.A.; Velarde, V.; Orellana, J.A. Interferon- $\gamma$ and high glucose-induced opening of Cx43 hemichannels causes endothelial cell dysfunction and damage. BBA Mol. Cell Res. 2020, 1867, 118720. [CrossRef]

49. Roy, S.; Jiang, J.X.; Li, A.F.; Kim, D. Connexin channel and its role in diabetic retinopathy. Prog. Retin. Eye Res. 2017, 61, 35. [CrossRef]

50. Lyon, H.; Shome, A.; Rupenthal, I.; Green, C.R.; Mugisho, O.O. Tonabersat inhibits connexin43 hemichannel opening and inflammasome activation in an in vitro retinal epithelial cell model of diabetic retinopathy. Int. J. Mol. Sci. 2020, 22, 298 [CrossRef]

51. Thakur, V.; Alcoreza, N.; Cazares, J.; Chattopadhyay, M. Changes in stress-mediated markers in a human cardiomyocyte cell line under hyperglycemia. Int. J. Mol. Sci. 2021, 22, 802. [CrossRef]

52. Kim, S.; Kwon, S. Podocytes and microRNA-30/Cx43 axis in diabetic nephropathy. Ann. Transl. Med. 2021, 9, 828. [CrossRef] [PubMed]

53. Jordan, K.; Chodock, R.; Hand, A.R.; Laird, D.W. The origin of annular junctions: A mechanism of gap junction internalization. J. Cell Sci. 2001, 114, 763-773. [CrossRef] [PubMed]

54. Pollack, R.; Donath, M.; LeRoith, D.; Leibowitz, G. Anti-inflammatory agents in the treatment of diabetes and its vascular complications. Diabetes Care 2016, 39, S244-S252. [CrossRef] 
55. Tsalamandris, S.; Antonopoulos, A.; Oikonomou, E.; Papamikroulis, G.A.; Vogiatzi, G.; Papaioannou, S.; Deftereos, S.; Tousoulis, D. The role of inflammation in diabetes: Current concepts and future perspectives. Eur. Cardiol. Rev. 2019, 14, 50-59. [CrossRef]

56. Teodoro, J.; Nunes, S.; Rolo, A.; Reis, F.; Palmeira, C.M. Therapeutic options targeting oxidative stress, mitochondrial dysfunction and inflammation to hinder the progression of vascular complications of diabetes. Front. Physiol. 2019, 10, 1857. [CrossRef] [PubMed]

57. Tseng, W.; Thein, T.; Kinnunen, K.; Lashkari, K.; Gregory, M.S.; D'Amore, P.A.; Ksander, B.R. NLRP3 inflammasome activation in retinal pigment epithelial cells by lysosomal destabilization: Implications for age-related macular degeneration. Investig. Ophth. Vis. Sci. 2013, 54, 110-120. [CrossRef]

58. Zhang, C.; Zhu, X.; Li, L.; Ma, T.; Shi, M.; Yang, Y.; Fan, Q. A small molecule inhibitor MCC950 ameliorates kidney injury in diabetic nephropathy by inhibiting NLRP3 inflammasome activation. DMSO Targets Ther. 2019, 12, 1297-1309. [CrossRef]

59. Palmer, A.; Tchkonia, T.; Kirkland, J. Senolytics: Potential for alleviating diabetes and its complications. Endocrinology 2021, 162, bqab058. [CrossRef] [PubMed]

60. Li, S.; Vandvik, P.; Lytvyn, L.; Guyatt, G.H.; Palmer, S.C.; Vermandere, M.; Rodriguez-Gutierrez, R.; Foroutan, F.; Agoritsas, T.; Siemieniuk, R.A.; et al. SGLT-2 inhibitors or GLP-1 receptor agonists for adults with type 2 diabetes: A clinical practice guideline. Br. Med. J. 2021, 8, 22. [CrossRef]

61. Lee, M.; Kim, B.; Han, K.; Lee, J.H.; Kim, M.; Kim, M.K.; Baek, K.; Song, K.; Kwon, H.; Roh, Y. Sodium-glucose cotransporter 2 inhibitors and risk of retinal vein occlusion among patients with type 2 diabetes: A propensity score-matched cohort study. Diabetes Care 2021, 44, 2419-2426. [CrossRef]

62. Petrie, J. SGLT2 inhibitors and renal complications in type 2 diabetes. Lancet Diabetes Endocrinol. 2020, 8, 803-805. [CrossRef]

63. Coll, R.; O'Neill, L.; Schroder, K. Questions and controversies in innate immune research: What is the physiological role of NLRP3? Nat. Publ. Group 2016, 2, 16019. [CrossRef] [PubMed]

64. Van der Heijden, T.; Kritikou, E.; Venema, W.; van Duijn, J.; van Santbrink, P.J.; Slütter, B.; Foks, A.C.; Bot, I.; Kuiper, J. NLRP3 inflammasome inhibition by MCC950 reduces atherosclerotic lesion development in apolipoprotein E-deficient mice-Brief report. Arterioscler. Thromb. Vasc. Biol. 2017, 37, 1457-1461. [CrossRef] [PubMed]

65. Khatri, V.; Kalyanasundaram, R. Therapeutic implications of inflammasome in inflammatory bowel disease. FASEB J. 2021, 35, e21439. [CrossRef] [PubMed]

66. Torres, S.; Brol, M.; Magdaleno, F.; Schierwagen, R.; Uschner, F.E.; Klein, S.; Ortiz, C.; Tyc, O.; Bachtler, N.; Stunden, J.; et al. The specific NLRP3 antagonist IFM-514 decreases fibrosis and inflammation in experimental murine non-alcoholic steatohepatitis. Front. Mol. Biosci. 2021, 8, 771. [CrossRef]

67. Ram, C.; Jha, A.; Ghosh, A.; Gairola, S.; Syed, A.M.; Murty, U.S.; Naidu, V.G.M.; Sahu, B.D. Targeting NLRP3 inflammasome as a promising approach for treatment of diabetic nephropathy: Preclinical evidences with therapeutic approaches. Eur. J. Pharmacol. 2020, 885, 173503. [CrossRef]

68. Sharma, A.; Choi, J.; Stefanovic, N.; Al-Sharea, A.; Simpson, D.S.; Mukhamedova, N.; Jandeleit-Dahm, K.; Murphy, A.J.; Sviridov, D.; Vince, J.E.; et al. Specific NLRP3 inhibition protects against diabetes-associated atherosclerosis. Diabetes 2021, 70, 772-787. [CrossRef]

69. Gora, I.; Ciechanowska, A.; Ladyzynski, P. NLRP3 inflammasome at the interface of inflammation, endothelial dysfunction, and type 2 diabetes. Cells 2021, 10, 314. [CrossRef] [PubMed]

70. Ge, K.; Wang, Y.; Li, P.; Li, M.; Zhang, W.; Dan, H.; Hu, X.; Zhou, J.; Yang, Q.; Wang, J.; et al. Down-expression of the NLRP3 inflammasome delays the progression of diabetic retinopathy. Microvasc. Res. 2021, 139, 104265. [CrossRef]

71. Huang, W.; Jiao, J.; Liu, J.; Huang, M.; Hu, Y.; Ran, W.; Yan, L.; Li, M.; Quan, Z.; Rao, Y.; et al. MFG-E8 accelerates wound healing in diabetes by regulating "NLRP3 inflammasome-neutrophil extracellular traps" axis. Cell Death Discov. 2020, 6, 84. [CrossRef]

72. He, X.; Li, L.; Xian, W.; Li, M.Y.; Zhang, L.Y.; Xu, J.H.; Pei, Z.; Zheng, H.Q.; Hu, X.Q. Chronic colitis exacerbates NLRP3-dependent neuroinflammation and cognitive impairment in middle-aged brain. J. Neuroinflamm. 2021, 18, 153. [CrossRef] [PubMed]

73. Paik, S.; Kim, J.; Silwal, P.; Sasakawa, C.; Jo, E.K. An update on the regulatory mechanisms of NLRP3 inflammasome activation. Cell. Mol. Immunol. 2021, 18, 1141-1160. [CrossRef]

74. Surabhi, S.; Cuypers, F.; Hammerschmidt, S.; Siemens, N. The role of NLRP3 inflammasome in Pneumococcal infections. Front. Immunol. 2020, 11, 3277. [CrossRef] [PubMed]

75. Zhao, C.; Zhao, W. NLRP3 inflammasome-A key player in antiviral responses. Front. Immunol. 2020, 11, 211. [CrossRef]

76. Zheng, D.; Liwinski, T.; Elinav, E. Inflammasome activation and regulation: Toward a better understanding of complex mechanisms. Cell Discov. 2020, 6, 36. [CrossRef] [PubMed]

77. Feng, Y.; Tan, Z.; Wang, M. Inhibition of NLRP3 inflammasome: A prospective target for the treatment of ischemic stroke. Front. Cell. Neurosci. 2020, 14, 155. [CrossRef]

78. Yang, Y.; Wang, H.; Jouadir, M. Recent advances in the mechanisms of NLRP3 inflammasome activation and its inhibitors. Cell Death Dis. 2019, 10, 97. [CrossRef]

79. Kelley, N.; Jeltema, D.; Duan, Y.; He, Y. The NLRP3 inflammasome: An overview of mechanisms of activation and regulation. Int. J. Mol. Sci. 2019, 20, 3328. [CrossRef]

80. He, Y.; Hara, H.; Núñez, G. Mechanism and regulation of NLRP3 inflammasome activation. Trends Biochem. Sci. 2016, 41, 1012-1021. [CrossRef] 
81. Wohlford, G.; Tassell, B.; Billingsley, H.; Kadariya, D.; Canada, J.M.; Carbone, S.; Mihalick, V.; Bonaventurea, A.; Vecchié, A.; Chiabrando, J.G.; et al. Single-center repeat dose safety and pharmacodynamics study of the oral NLRP3 inhibitor Dapansutrile in subjects with NYHA II-III systolic heart failure. J. Cardiovasc. Pharmacol. 2019, 77, 49-60. [CrossRef]

82. El-Sharkawy, L.; Brough, D.; Freeman, S. Inhibiting the NLRP3 inflammasome. Molecules 2020, 25, 5533. [CrossRef]

83. Ridker, P.; MacFadyen, J.; Everett, B.; Libby, P.; Thuren, T.; Glynn, R.J. Relationship of C-reactive protein reduction to cardiovascular event reduction following treatment with canakinumab: A secondary analysis from the CANTOS randomized controlled trial. Lancet 2018, 391, 319-328. [CrossRef]

84. Ruperto, N.; Brunner, H.; Quartier, P.; Constantin, T.; Wulffraat, N.M.; Horneff, G.; Kasapcopur, O.; Schneider, R.; Anton, J.; Barash, J.; et al. Canakinumab in patients with systemic juvenile idiopathic arthritis and active systemic features: Results from the 5-year long-term extension of the phase III pivotal trials. Ann. Rheum. Dis. 2018, 77, 1710-1719. [CrossRef]

85. Moran, A.; Bundy, B.; Becker, D.J.; Dimeglio, L.A.; Gitelman, S.E.; Goland, R. Interleukin-1 antagonism in type 1 diabetes of recent onset: Two multicentre, randomized, double-blind, placebo-controlled trials. Lancet 2013, 381, 1905-1915. [CrossRef]

86. Ridker, P.; Howard, C.; Walter, V.; Everett, B.; Libby, P.; Hensen, J.; Thuren, T. Effects of interleukin-1ß inhibition with canakinumab on hemoglobin A1c, lipids, C-reactive protein, interleukin-6, and fibrinogen: A phase IIb randomized, placebo-controlled trial. Circulation 2012, 126, 2739-2748. [CrossRef]

87. Ridker, P.; Everett, B.; Thuren, T.; MacFadyen, J.G.; Chang, W.H.; Ballantyne, C.; Fonseca, F.; Nicolau, J.; Koenig, W.; Anker, S.D.; et al. Antiinflammatory therapy with Canakinumab for atherosclerotic disease. N. Engl. J. Med. 2017, 377, 1119-1131. [CrossRef]

88. Kiyoshi, M.; Tatematsu, K.; Tada, M.; Sezutsu, H.; Shibata, H.; Ishii-Watabe, A. Structural insight and stability of TNFR-Fc fusion protein (Etanercept) produced by transgenic silkworms. J. Biochem. 2021, 169, 25-33. [CrossRef] [PubMed]

89. Stevenson, M.; Archer, R.; Tosh, J.; Simpson, E.; Everson-Hock, E.; Stevens, J.; Hernandez-Alava, M.; Paisley, S.; Dickinson, K.; Scott, D.; et al. Adalimumab, etanercept, infliximab, certolizumab pegol, golimumab, tocilizumab and abatacept for the treatment of rheumatoid arthritis not previously treated with disease-modifying antirheumatic drugs and after the failure of conventional disease-modifying antirheumatic drugs only: Systematic review and economic evaluation. Health Technol. Assess. 2016, 35, 1-610. [CrossRef]

90. Kawanami, D.; Matoba, K.; Takeda, Y.; Negai, Y.; Akamine, T.; Yokota, T.; Sango, K.; Utsunomiya, K. SGLT2 inhibitors as a therapeutic option for diabetic nephropathy. Int. J. Mol. Sci. 2017, 18, 1083. [CrossRef] [PubMed]

91. McGuire, D.K.; Shih, W.J.; Cosentino, F.; Charbonnel, B.; Cherney, D.Z.I.; Dagogo-Jack, S.; Pratley, R.; Greenberg, M.; Wang, S.; Huyck, S.; et al. Association of SGLT2 inhibitors with cardiovascular and kidney outcomes in patients with type 2 diabetes: A meta-analysis. JAMA Cardiol. 2021, 6, 148-158. [CrossRef] [PubMed]

92. Schmidt, D.; Argyropoulos, C.; Singh, N. Are the protective effects of SGLT2 inhibitors a "class-effect" or are there differences between agents? Kidney360 2021, 2, 881-885. [CrossRef]

93. Liu, H.; Sridhar, V.; Boulet, J.; Dharia, A.; Khan, A.; Lawler, P.R.; Cherney, D.Z.I. Cardiorenal protection with SGLT2 inhibitors in patients with diabetes mellitus: From biomarkers to clinical outcomes in heart failure and diabetic kidney disease. Metab. Clin. Exp. 2021, 126, 154918. [CrossRef] [PubMed]

94. Thirunavukarasu, S.; Jex, N.; Chowdhary, A.; Hassan, I.U.; Straw, S.; Craven, T.P.; Gorecka, M.; Broadbent, D.; Swoboda, P.; Witte, K.K.; et al. Empagliflozin treatment is associated with improvements in cardiac energetics and function and reductions in myocardial cellular volume in patients with type 2 diabetes. Diabetes 2021, 70, db210270. [CrossRef] [PubMed]

95. D’Onofrio, N.; Sardu, C.; Trotta, M.; Scisciola, L.; Turriziani, F.; Ferreraccio, F.; Panarese, I.; Petrella, L.; Fanelli, M.; Modugno, P.; et al. Sodium-glucose co-transporter2 expression and inflammatory activity in diabetic atherosclerotic plaques: Effects of sodium-glucose co-transporter2 inhibitor treatment. Mol. Metab. 2021, 54, 101337. [CrossRef] [PubMed]

96. Xu, J.; Kitada, M.; Ogura, Y.; Liu, H.; Koya, D. Dapagliflozin Restores Impaired Autophagy and Suppresses Inflammation in High Glucose-Treated HK-2 Cells. Cells 2021, 10, 1457. [CrossRef]

97. Madonna, R.; Doria, V.; Minnucci, I.; Pucci, A.; Pierdomenico, D.S.; de Caterina, R. Empagliflozin reduces the senescence of cardiac stromal cells and improves cardiac function in a murine model of diabetes. J. Cell. Mol. Med. 2020, 24, 12331-12340. [CrossRef]

98. Musso, G.; Saba, F.; Cassader, M.; Gambino, R. Diabetic ketoacidosis with SGLT2 inhibitors. BMJ 2020, 371, m4147. [CrossRef]

99. Lin, C.; Zhu, X.; Cai, X.; Yang, W.; Lv, F.; Nie, L.; Ji, L. SGLT2 inhibitors and lower limb complications: An updated meta-analysis. Cardiovasc. Diabetol. 2021, 20,1-12. [CrossRef]

100. Unnikrishnan, A.; Kalra, S.; Purandare, V.; Vasnawala, H. Genital infections with sodium glucose cotransporter-2 inhibitors: Occurrence and management in patients with type 2 diabetes mellitus. Indian J. Endocrinol. Metab. 2018, 22, 837-842. [CrossRef]

101. Lissoni, A.; Wang, N.; Nezlobinskii, T.; de Smet, M.; Panfilov, A.V.; Vandersickel, N.; Leybaert, L.; Witschas, K. Gap19, a Cx43 hemichannel inhibitor, acts as a gating modifier that decreases main state opening while increasing substrate gating. Int. J. Mol. Sci. 2020, 21, 7340. [CrossRef] [PubMed]

102. Delvaeye, T.; Smet, M.; Verwaerde, S.; Decrock, E.; Czekaj, A.; Wandenbroucke, R.E.; Lemeire, K.; Gonçalves, A.; Declercq, W.; Vandenabeele, P.; et al. Blocking connexin 43 hemichannels protects mice against tumour necrosis factor-induced inflammatory shock. Sci. Rep. 2019, 9, 16623. [CrossRef] [PubMed]

103. Kim, Y.; Griffith, J.; Nor, M.; Zhang, J.; Freestnoe, P.S.; Danesh-Meyer, H.V.; Rupenthal, I.D.; Acosta, M.; Nicholson, L.F.B.; O'Carroll, S.J.; et al. Tonabersat Prevents Inflammatory Damage in the Central Nervous System by Blocking Connexin43 Hemichannels. Neurother. J. Am. Soc. Exp. Neurother. 2017, 14, 1148-1165. [CrossRef] 
104. King, D.; Sedovy, M.; Leng, X.; Xue, J.; Lamouille, S.; Koval, M.; Isakson, B.E.; Johnstone, S.R. Mechanisms of connexin mimetic peptides. Int. J. Mol. Sci. 2021, 22, 10186. [CrossRef] [PubMed]

105. Mugisho, O.; Green, C.; Kho, D.; Zhang, J.; Graham, E.S.; Acosta, M.L.; Rupenthal, I.D. The inflammasome pathway is amplified and perpetuated in an autocrine manner through connexin 43 hemichannel mediated ATP release. Biochim. Biophys. Acta 2018, 1862, 385-393. [CrossRef] [PubMed]

106. Lee, S.; Kim, S.; Park, H.; Lee, Y.J.; Park, S.H.; Lee, K.J.; Lee, D.G.; Kang, H.; Kim, J.E. Contribution of autophagy-notch1-mediated nlrp3 inflammasome activation to chronic inflammation and fibrosis in keloid fibroblasts. Int. J. Mol. Sci. 2020, 21, 8050. [CrossRef]

107. Van Campenhout, R.; Gomes, A.; Groof, T.; Muyldermans, S.; Devoogdt, N.; Vinken, M. Mechanisms underlying connexin hemichannel activation in disease. Int. J. Mol. Sci. 2021, 22, 3503. [CrossRef]

108. Price, G.W.; Chadjichristos, C.; Kavvadas, P.; Tang, S.C.W.; Yiu, W.H.; Green, C.R.; Potter, J.A.; Siamantouras, E.; Squires, P.E.; Hills, C.E. Blocking Connexin-43 mediated hemichannel activity protects against early tubular injury in experimental chronic kidney disease. Cell Commun. Signal. 2020, 18, 1-17. [CrossRef]

109. Laird, D.; Lampe, P. Therapeutic strategies targeting connexins. Nat. Rev. Drug Discov. 2018, 17, 905. [CrossRef]

110. Rhett, J.M.; Yeh, E.S. Molecular Sciences the Potential for Connexin Hemichannels to Drive Breast Cancer Progression through Regulation of the Inflammatory Response. Int. J. Mol. Sci. 2018, 19, 1043. [CrossRef] [PubMed]

111. Simon, Á.; Magyar, C.; Héja, L.; Kardos, J. Peptide binding sites of connexin proteins. Chemistry 2020, 2, 662-673. [CrossRef]

112. Wang, N.; Bock, M.; Antoons, G.; Gadicharla, A.K.; Bol, M.; Decrock, E.; Evans, W.H.; Sipido, K.R.; Bukauskas, F.F.; Leybaert, L. Connexin mimetic peptides inhibit Cx43 hemichannel opening triggered by voltage and intracellular Ca2+ elevation. Basic Res. Cardiol. 2012, 107, 304. [CrossRef]

113. Montgomery, J.; Ghatnekar, G.; Grek, C.; Moyer, K.E.; Gourdie, R.G. Connexin 43-Based Therapeutics for Dermal Wound Healing Int. J. Mol. Sci. 2018, 19, 1778. [CrossRef]

114. Evans, W.; Leybaert, L. Mimetic Peptides as Blockers of Connexin Channel-Facilitated Intercellular Communication. Cell Commun. Adhes. 2007, 14, 265-273. [CrossRef]

115. Abudara, V.; Bechberger, J.; Freitas-Andrade, M.; de Bock, M.; Wang, N.; Bultynck, G.; Naus, C.C.; Leybaert, L.; Giaume, C. The connexin43 mimetic peptide Gap19 inhibits hemichannels without altering gap junctional communication in astrocytes. Front. Cell. Neurosci. 2014, 8, 306. [CrossRef]

116. Coutinho, F.; Green, C.; Acosta, M.; Rupenthal, I.D. Xentry-Gap19 inhibits Connexin43 hemichannel opening especially during hypoxic injury. Drug Deliv. Transl. Res. 2020, 10, 751-765. [CrossRef] [PubMed]

117. Wang, N.; Vuyst, E.; Ponsaerts, R.; Boengler, K.; Palacios-Prado, N.; Wauman, J.; Lai, C.P.; de Bock, M.; Decrock, E.; Bol, M.; et al. Selective inhibition of Cx43 hemichannels by Gap19 and its impact on myocardial ischemia/reperfusion injury. Basic Res. Cardiol. 2013, 108, 1-16. [CrossRef]

118. Chen, B.; Yang, L.; Chen, J.; Chen, Y.; Zhang, L.; Wang, L.; Li, X.; Li, Y.; Yu, H. Inhibition of Connexin43 hemichannels with Gap19 protects cerebral ischemia/reperfusion injury via the JAK2/STAT3 pathway in mice. Brain Res. Bull. 2019, 146, 124-135. [CrossRef] [PubMed]

119. Maes, M.; Yanguas, S.C.; Willebrords, J.; Weemhoff, J.L. Connexin hemichannel inhibition reduces acetaminophen-induced liver injury in mice. Toxicol. Lett. 2017, 278, 30-37. [CrossRef]

120. Tarzemany, R.; Jiang, G.; Jiang, J.; Larjava, H.; Häkkinen, L. Connexin 43 Hemichannels Regulate the Expression of Wound Healing-Associated Genes in Human Gingival Fibroblasts. Sci. Rep. 2017, 7, 1-15. [CrossRef]

121. Warner, A.; Clements, D.; Parikh, S.; Evans, W.H.; DeHaan, R.L. Specific motifs in the external loops of connexin proteins can determine gap junction formation between chick heart myocytes. J. Physiol. 1995, 488, 721-728. [CrossRef]

122. Orellana, J.; Shoji, K.; Abudara, V.; Ezan, P.; Amigou, E.; Sáez, P.J.; Jiang, J.X.; Naus, C.C.; Sáez, J.C.; Giaume, C. Amyloid $\beta$-induced death in neurons involves glial and neuronal hemichannels. J. Neurosci. 2011, 31, 4962-4977. [CrossRef] [PubMed]

123. Elbadawy, H.M.; Mirabelli, P.; Xeroudaki, M.; Parekh, M.; Bertolin, M.; Breda, C.; Cagini, C.; Ponzin, D.; Lagali, N.; Ferrari, S Effect of connexin 43 inhibition by the mimetic peptide Gap27 on corneal wound healing, inflammation and neovascularization. Br. J. Pharmacol. 2016, 173, 2880-2893. [CrossRef] [PubMed]

124. Faniku, C.; O'Shaughnessy, E.; Lorraine, C.; Johnstone, S.R.; Graham, A.; Greenhough, S.; Martin, P.E.M. The Connexin Mimetic Peptide Gap27 and Cx43-Knockdown Reveal Differential Roles for Connexin43 in Wound Closure Events in Skin Model Systems. Int. J. Mol. Sci. 2018, 19, 604. [CrossRef] [PubMed]

125. Kuo, C.; Green, C.; Rupenthal, I.; Mugisho, O.O. Connexin43 hemichannel block protects against retinal pigment epithelial cell barrier breakdown. Acta Diabetol. 2020, 57, 13-22. [CrossRef] [PubMed]

126. Guo, C.; Nor, M.; Danesh-Meyer, H.; Vessey, K.A.; Fletcher, E.L.; O'Carroll, S.J.; Acosta, M.L.; Green, C.R. Connexin43 Mimetic Peptide Improves Retinal Function and Reduces Inflammation in a Light-Damaged Albino Rat Model. Investig. Opth. Vis. Sci. 2016, 57, 3961-3973. [CrossRef]

127. Nor, M.N.M.; Rupenthal, I.D.; Green, C.R.; Acosta, M.L. Connexin hemichannel block using orally delivered Tonabersat improves outcomes in animal models of retinal disease. Neurotherapeutics 2020, 17, 371-387. [CrossRef]

128. Jiang, J.; Hoagland, D.; Palatinus, J.; He, H.; Iyyathurai, J.; Jourdan, J.; Bultynck, G.; Wang, Z.; Zhang, Z.; Schey, K.; et al Interaction of $\alpha$ Carboxyl Terminus 1 Peptide with the Connexin 43 Carboxyl Terminus Preserves Left Ventricular Function After Ischemia-Reperfusion Injury. J. Am. Heart Assoc. 2019, 8, e012385. [CrossRef] 
129. O'Quinn, M.P.; Palatinus, J.A.; Harris, B.S.; Hewett, K.W.; Gourdie, R.G. A peptide mimetic of the connexin43 carboxyl terminus reduces gap junction remodeling and induced arrhythmia following ventricular injury. Circ Res. 2011, 108, 704-715. [CrossRef]

130. Moore, K.; Bryant, Z.; Ghatnekar, G.; Singh, U.P.; Gourdie, R.G.; Potts, J.D. A Synthetic Connexin 43 Mimetic Peptide Augments Corneal Wound Healing. Exp. Eye Res. 2013, 115, 178-188. [CrossRef]

131. Grek, C.; Montgomery, J.; Sharma, M.; Ravi, A.; Rajkumar, J.S.; Moyer, K.E.; Gourdie, R.G.; Ghatnekar, G.S. A Multicenter Randomized Controlled Trial Evaluating a Cx43-Mimetic Peptide in Cutaneous Scarring. J. Investig. Dermatol. 2017, 137, 620. [CrossRef]

132. Montgomery, J.; Richardson, W.; Marsh, S.; Rhett, M.; Bustos, F.; Degen, K.; Ghatnekar, G.S.; Grek, C.L.; Jourdan, L.J.; Holmes, J.W.; et al. The connexin 43 carboxyl terminal mimetic peptide $\alpha \mathrm{CT} 1$ prompts differentiation of a collagen scar matrix in humans resembling unwounded skin. FASEB J. 2020, 35, e21762. [CrossRef]

133. Butera, J.; Larsen, B.; Herman, J.; Kerns, E.; Di, L.; Alimardanov, A.; Swillo, R.E.; Morgan, G.A.; Liu, K.; Wang, Q.; et al Discovery of (2S,4R)-1-(2-aminoacetyl)-4-benzamidopyrrolidine-2-carboxylic acid hydrochloride (GAP-134)13, an orally active small molecule gap-junction modifier for the treatment of atrial fibrillation. J. Med. Chem. 2009, 52, 908-911. [CrossRef]

134. Kim, D.; Mouritzen, U.; Larsen, B.D.; Roy, S. Inhibition of Cx43 gap junction uncoupling prevents high glucose-induced apoptosis and reduces excess cell monolayer permeability in retinal vascular endothelial cells. Exp. Eye Res. 2018, 173, 85-90. [CrossRef]

135. Squires, P.; Price, G.W.; Mouritzen, U.; Potter, J.A.; Williams, B.M.; Hills, C.E. Danegaptide Prevents TGF $\beta 1$-Induced Damage in Human Proximal Tubule Epithelial Cells of the Kidney. Int. J. Mol. Sci. 2021, 22, 2809. [CrossRef]

136. Skyschally, A.; Walter, B.; Hansen, R.; Heusch, G. The antiarrhythmic dipeptide ZP1609 (danegaptide) when given at reperfusion reduces myocardial infarct size in pigs. Naunyn. Schmiedebergs Arch. Pharmacol. 2013, 386, 383-391. [CrossRef] [PubMed]

137. Hennan, J.K.; Swillo, R.E.; Morgan, G.A.; Rossman, E.I.; Kantrowitz, J.; Butera, J.; Peterson, J.S.; Gardell, S.J.; Vlasuk, G.P. GAP-134 ([2S,4R]-1-[2-Aminoacetyl]4-Bensamidopyrrolidine-2-Carboxylic Acid] prevents spontaneous ventricular arrhythmias and reduces infarct size during myocardial ischemia/reperfusion injury in open-chest dogs. J. Cardiovasc. Pharmacol. Ther. 2009, 14, 207-214. [CrossRef] [PubMed]

138. Laurent, G.; Howard, L.P.; Mangat, I.; Moe, G.W.; Hu, X.; So, P.P.; Tarulli, E.; Ramadeen, A.; Rossman, E.I.; Hennan, J.K.; et al Effects of chronic gap junction conduction-enhancing antiarrhythmic peptide GAP-134 administration on experimental atrial fibrillation in dogs. Circ. Arrhythmia Electrophysiol. 2009, 2, 171-178. [CrossRef] [PubMed]

139. Rossman, E.I.; Liu, K.; Morgan, G.A.; Swillo, R.E.; Krueger, J.A.; Gardell, S.J.; Butera, J.; Gruver, M.; Kantrowitz, J.; Feldman, H.S.; et al. The gap junction modifier, GAP-134 [(2S,4R]-1-[2-Aminoacetyl]4-Bensamidopyrrolidine-2-Carboxylic Acid], improves conduction and reduces atrial fibrillation/flutter in the canine sterile pericarditis model. J. Pharmacol. Exp. Ther. 2009, 329, 1127-1133. [CrossRef]

140. Ilyas, Z.; Chaiban, J.T.; Krikorian, A. Novel insights into the pathophysiology and clinical aspects of diabetic nephropathy. Rev. Endocr. Metab. Disord. 2017, 18, 21-28. [CrossRef]

141. Kravets, I.; Mallipattu, S.K. The Role of Podocytes and Podocyte-Associated Biomarkers in Diagnosis and Treatment of Diabetic Kidney Disease. J. Endocr. Soc. 2020, 4, bvaa029. [CrossRef]

142. Weil, E.J.; Lemley, K.V.; Mason, C.C.; Yee, B.; Jones, L.I.; Blouch, K.; Lovato, T.; Richardson, M.; Myers, B.D.; Nelson, R.G. Podocyte detachment and reduced glomerular capillary endothelial fenestration promote kidney disease in type 2 diabetic nephropathy. Kidney Int. 2012, 82, 1010-1017. [CrossRef] [PubMed]

143. Nunes, S.; Alves, A.; Preguiça, I.; Barbosa, A.; Vieira, P.; Mendes, F.; Martins, D.; Viana, S.D.; Reis, F. Crescent-Like Lesions as an Early Signature of Nephropathy in a Rat Model of Prediabetes Induced by a Hypercaloric Diet. Nutrients 2020, 12, 881. [CrossRef] [PubMed]

144. Liu, Y.; Huang, H.; Gao, R.; Liu, Y. Dynamic Phenotypes and Molecular Mechanisms to Understand the Pathogenesis of Diabetic Nephropathy in Two Widely Used Animal Models of Type 2 Diabetes Mellitus. Front. Cell Dev. Biol. 2020, 8, 172. [CrossRef] [PubMed]

145. Zhang, X.; Yang, Y.; Zhao, Y. Macrophage phenotype and its relationship with renal function in human diabetic nephropathy PLoS ONE 2019, 14, e0221991. [CrossRef]

146. Xiong, J.; Wang, Y.; Shao, N.; Gao, P.; Tang, H.; Su, H.; Zhang, C.; Meng, X.F. The Expression and Significance of NLRP3 Inflammasome in Patients with Primary Glomerular Diseases. Kidney Blood Press. Res. 2015, 40, 344-354. [CrossRef]

147. Kavvadas, P.; Abed, A.; Poulain, C.; Authier, F.; Labéjof, L.P.; Calmont, A.; Afieri, C.; Prakoura, N.; Dussaule, J.C.; Chatziantoniou, C.; et al. Decreased expression of connexin 43 blunts the progression of experimental GN. J. Am. Soc. Nephrol. 2017, 28, 2915-2930. [CrossRef]

148. Ougaard, M.K.E.; Kvist, P.H.; Jensen, H.E.; Hess, C.; Rune, I.; Søndergaard, H. Murine Nephrotoxic Nephritis as a Model of Chronic Kidney Disease. Int. J. Nephrol. 2018, 2018, 8424502. [CrossRef]

149. Ji, J.; Zhao, Y.; Na, C.; Yang, M.; Zhu, X.; Shi, H.; Gan, W.; Zhang, A. Connexin 43-autophagy loop in the podocyte injury of diabetic nephropathy. Int. J. Mol. Med. 2019, 44, 1781-1788. [CrossRef]

150. Liu, B.C.; Tang, T.T.; Lv, L.L.; Lan, H.Y. Renal tubule injury: A driving force toward chronic kidney disease. Kidney Int. 2018, 93 , 568-579. [CrossRef]

151. Hills, C.; Price, G.W.; Wall, M.J.; Kaufmann, T.J.; Chi-Wai Tang, S.; Yiu, W.H.; Squires, P.E. Transforming Growth Factor Beta 1 Drives a Switch in Connexin Mediated Cell-to-Cell Communication in Tubular Cells of the Diabetic Kidney. Cell. Physiol. Biochem. 2018, 45, 2369-2388. [CrossRef] 
152. Potter, J.A.; Price, G.W.; Cliff, C.L.; Green, C.R.; Squires, P.E.; Hills, C.E. Collagen I modifies connexin-43 hemichannel activity via integrin $\alpha 2 \beta 1$ binding in TGF $\beta 1$-evoked renal tubular epithelial cells. Int. J. Mol. Sci. 2021, 22, 3644. [CrossRef]

153. Hills, C.E.; Price, G.W.; Squires, P.E. Mind the gap: Connexins and cell-cell communication in the diabetic kidney. Diabetologia 2015, 58, 233-241. [CrossRef]

154. Siamantouras, E.; Hills, C.E.; Liu, K.K.; Squires, P.E. Examining Cell-Cell Interactions in the Kidney Using AFM Single-Cell Force Spectroscopy. Methods Mol. Biol. 2020, 2067, 189-201. [CrossRef]

155. Siamantouras, E.; Hills, C.E.; Squires, P.E.; Liu, K.K. Quantifying cellular mechanics and adhesion in renal tubular injury using single cell force spectroscopy. Nanomedicine 2016, 12, 1013-1021. [CrossRef] [PubMed]

156. Siamantouras, E.; Price, G.W.; Potter, J.A.; Hills, C.E.; Squires, P.E. Purinergic receptor (P2X7) activation reduces cell-cell adhesion between tubular epithelial cells of the proximal kidney. Nanomed. Nanotechnol. Biol. Med. 2019, 22, 102108. [CrossRef] [PubMed]

157. Menzies, R.I.; Booth, J.W.R.; Mullins, J.J.; Bailey, M.A.; Tam, F.W.K.; Norman, J.T.; Unwin, R.J. Hyperglycemia-induced Renal P2X7 Receptor Activation Enhances Diabetes-related Injury. EBioMedicine 2017, 19, 73-83. [CrossRef] [PubMed]

158. Bao, Y.-W.; Yuan, Y.; Chen, J.-H.; Lin, W.-Q. Kidney disease models: Tools to identify mechanisms and potential therapeutic targets. Sci. Press Zool. Res. 2018, 39, 72-86. [CrossRef]

159. McHugh, S.M.; Roman, S.; Davis, B.; Koch, A.; Pickett, A.M.; Richardson, J.C.; Miller, S.R.; Wetten, S.; Cox, C.J.; Karpe, F.; et al Effects of genetic variation in the P2RX7 gene on pharmacodynamics of a P2X7 receptor antagonist: A prospective genotyping approach. Br. J. Clin. Pharmacol. 2012, 74, 376-380. [CrossRef]

160. Burnstock, G.; Knight, G.E. The potential of P2X7 receptors as a therapeutic target, including inflammation and tumour progression. Purinergic Signal. 2018, 14, 1-18. [CrossRef]

161. Sun, X.-h.; Xiao, H.-m.; Zhang, M.; Lin, Z.-y.; Yang, Y.; Chen, R.; Liu, P.-q.; Huang, K.-p.; Huang, H.-q. USP9X deubiquitinates connexin43 to prevent high glucose-induced epithelial-to-mesenchymal transition in NRK-52E cells. Biochem. Pharmacol. 2021, 188, 114562. [CrossRef]

162. Lucero, C.M.; Andrade, D.C.; Toledo, C.; Díaz, H.S.; Pereyra, K.V.; Diaz-Jara, E.; Schwarz, K.G.; Marcus, N.J.; Retamal, M.A.; Quintanilla, R.A.; et al. Cardiac remodeling and arrhythmogenesis are ameliorated by administration of Cx43 mimetic peptide Gap27 in heart failure rats. Sci. Rep. 2020, 10,1-12. [CrossRef]

163. Tonkin, R.S.; Bowles, C.; Perera, C.J.; Keating, B.A.; Makker, P.G.S.; Duffy, S.S.; Lees, J.G.; Tran, C.; Don, A.S.; Fath, T.; et al. Attenuation of mechanical pain hypersensitivity by treatment with Peptide5, a connexin-43 mimetic peptide, involves inhibition of NLRP3 inflammasome in nerve-injured mice. Exp. Neurol. 2018, 300, 1-12. [CrossRef]

164. Hills, C.E.; Squires, P.E. TGF- $\beta 1$-Induced Epithelial-to-Mesenchymal Transition and Therapeutic Intervention in Diabetic Nephropathy. Am. J. Nephrol. 2010, 31, 68-74. [CrossRef]

165. Davidson, J.O.; Green, C.R.; Louise, L.F.; O'Carroll, S.J.; Fraser, M.; Bennet, L.; Jan Gunn, A. Connexin hemichannel blockade improves outcomes in a model of fetal ischemia. Ann. Neurol. 2012, 71, 121-132. [CrossRef]

166. Danesh-Meyer, H.V.; Kerr, N.M.; Zhang, J.; Eady, E.K.; O'Carroll, S.J.; Nicholson, L.F.B.; Johnson, C.S.; Green, C.R. Connexin43 mimetic peptide reduces vascular leak and retinal ganglion cell death following retinal ischaemia. Brain 2012, 135, 506-520. [CrossRef]

167. Hills, C.E.; Squires, P.E. The role of TGF- $\beta$ and epithelial-to mesenchymal transition in diabetic nephropathy. Cytokine Growth Factor Rev. 2011, 22, 131-139. [CrossRef] [PubMed]

168. Abed, A.; Toubas, J.; Kavvadas, P.; Authier, F.; Cathelin, D.; Alfieri, C.; Boffa, J.-J.; Dussaule, J.-C.; Chatziantoniou, C.; Chadjichristos, C.E. Targeting connexin 43 protects against the progression of experimental chronic kidney disease in mice. Kidney Int. 2014, 86, 768-779. [CrossRef] [PubMed]

169. Du, Q.; Fu, Y.-x.; Shu, A.-m.; Lv, X.; Chen, Y.-p.; Gao, Y.-y.; Chen, J.; Wang, W.; Lv, G.-h.; Lu, J.-f.; et al. Loganin alleviates macrophage infiltration and activation by inhibiting the MCP-1/CCR2 axis in diabetic nephropathy. Life Sci. 2021, 272, 118808. [CrossRef] [PubMed]

170. Yan, Q.; Jiang, H.; Wang, B.; Sui, W.; Zhou, H.; Zou, G. Expression and Significance of RANTES and MCP-1 in Renal Tissue with Chronic Renal Allograft Dysfunction. Transplant. Proc. 2016, 48, 2034-2039. [CrossRef]

171. Yang, J.; Lin, S.C.; Chen, G.; He, L.; Hu, Z.; Chan, L.; Trial, J.A.; Entman, M.L.; Wang, Y. Adiponectin promotes monocyte-tofibroblast transition in renal fibrosis. J. Am. Soc. Nephrol. 2013, 24, 1644-1659. [CrossRef]

172. National Diabetes Statistics Report. 2020. Available online: https://www.cdc.gov/diabetes/pdfs/data/statistics/nationaldiabetes-statistics-report.pdf (accessed on 24 November 2021).

173. Mathebula, S.D. Biochemical changes in diabetic retinopathy triggered by hyperglycaemia: A review. Afr. Vis. Eye Health 2018, 77, 1-7. [CrossRef]

174. Maugeri, G.; Bucolo, C.; Drago, F.; Rossi, S.; di Rosa, M.; Imbesi, R.; D’Agata, V.; Giunta, S. Attenuation of High Glucose-Induced Damage in RPE Cells through p38 MAPK Signaling Pathway Inhibition. Front. Pharmacol. 2021, 12, 1125. [CrossRef]

175. Mehanna, C.J.; Abdul Fattah, M.; Haddad, S.; Tamim, H.; Ghazi, N.; Salti, H. Anti-VEGF Therapy for Persistent Neovascularization after Complete Panretinal Photocoagulation in Proliferative Diabetic Retinopathy. Ophthalmol. Retin. 2019, 3, 473-477. [CrossRef] [PubMed]

176. Teo, Z.L.; Tham, Y.C.; Yu, M.; Chee, M.L.; Rim, T.H.; Cheung, N.; Bikbov, M.M.; Wang, Y.X.; Tang, Y.; Lu, Y.; et al. Global Prevalence of Diabetic Retinopathy and Projection of Burden through 2045: Systematic Review and Meta-analysis. Ophthalmology 2021, 128, 1580-1591. [CrossRef] 
177. Everett, L.A.; Paulus, Y.M. Laser Therapy in the Treatment of Diabetic Retinopathy and Diabetic Macular Edema. Curr. Diab. Rep. 2021, 21, 1-12. [CrossRef] [PubMed]

178. Zhao, Y.; Singh, R.P. The role of anti-vascular endothelial growth factor (anti-VEGF) in the management of proliferative diabetic retinopathy. Drugs Context 2018, 7, 212532. [CrossRef]

179. Che, D.; Zhou, T.; Lan, Y.; Xie, J.; Gong, H.; Li, C.; Feng, J.; Hong, H.; Qi, W.; Ma, C.; et al. High glucose-induced epithelialmesenchymal transition contributes to the upregulation of fibrogenic factors in retinal pigment epithelial cells. Int. J. Mol. Med. 2016, 38, 1815-1822. [CrossRef] [PubMed]

180. Lyon, H.; Yin, N.; Rupenthal, I.D.; Green, C.R.; Odunayo, I.; Mugisho, O. Blocking connexin 43 hemichannels prevents TGF- $\beta 2$ upregulation and epithelial-mesenchymal transition in retinal pigment epithelial cells. Cell Biol. Int. 2021. [CrossRef]

181. Mugisho, O.O.; Green, C.R.; Squirrell, D.M.; Bould, S.; Danesh-Meyer, H.V.; Zhang, J.; Acosta, M.L.; Rupenthal, I.D. Connexin43 hemichannel block protects against the development of diabetic retinopathy signs in a mouse model of the disease. J. Mol. Med. 2019, 97, 215-229. [CrossRef] [PubMed]

182. Mugisho, O.O.; Green, C.R.; Zhang, J.; Binz, N.; Acosta, M.L.; Rakoczy, E.; Rupenthal, I.D. Immunohistochemical Characterization of Connexin43 Expression in a Mouse Model of Diabetic Retinopathy and in Human Donor Retinas. Int. J. Mol. Sci. 2017, 18, 2567. [CrossRef]

183. Mugisho, O.O.; Rupenthal, I.D.; Squirrell, D.M.; Bould, S.J.; Danesh-Meyer, H.V.; Zhang, J.; Green, C.R.; Acosta, M.L. Intravitreal pro-inflammatory cytokines in non-obese diabetic mice: Modelling signs of diabetic retinopathy. PLoS ONE 2018, 13, e0202156. [CrossRef] [PubMed]

184. Louie, H.H.; Shome, A.; Kuo, C.Y.; Rupenthal, I.D.; Green, C.R.; Mugisho, O.O. Connexin43 hemichannel block inhibits NLRP3 inflammasome activation in a human retinal explant model of diabetic retinopathy. Exp. Eye Res. 2021, 202, 108384. [CrossRef] [PubMed]

185. Green, C.R.; Mat Nor, M.N.; Mugisho, O.O.; Rupenthal, I.D.; Squirrell, D.M.; Acosta, M.L. Connexin hemichannel block shuts down inflammation in an animal model of chronic diabetic retinopathy to improve structural and functional outcomes I IOVS I ARVO Journals. Investig. Ophthalmol. Vis. Sci. 2019, 60, 2784.

186. Tien, T.; Muto, T.; Zhang, J.; Sohn, E.H.; Mullins, R.F.; Roy, S. Association of reduced Connexin 43 expression with retinal vascular lesions in human diabetic retinopathy. Exp. Eye Res. 2016, 146, 103-106. [CrossRef]

187. Li, A.F.; Roy, S. High glucose-induced downregulation of connexin 43 expression promotes apoptosis in microvascular endothelial cells. Investig. Ophthalmol. Vis. Sci. 2009, 50, 1400-1407. [CrossRef]

188. Li, A.F.; Sato, T.; Haimovici, R.; Okamoto, T.; Roy, S. High Glucose Alters Connexin 43 Expression and Gap Junction Intercellular Communication Activity in Retinal Pericytes. Investig. Ophthalmol. Vis. Sci. 2003, 44, 5376-5382. [CrossRef]

189. European Commission (DG ECFIN) and Economic Policy Committee (Ageing Working Group). The 2015 Ageing Report Economic and Budgetary Projections for the 28 EU Member States (2013-2060). Available online: https:/ / ec.europa.eu/economy_ finance/publications/european_economy/2015/pdf/ee3_en.pdf (accessed on 24 November 2021).

190. Raman, K.S.; Matsubara, J.A. Dysregulation of the NLRP3 Inflammasome in Diabetic Retinopathy and Potential Therapeutic Targets. Ocul. Immunol. Inflamm. 2020, 1-9. [CrossRef]

191. Moreno, J.A.; Gomez-Guerrero, C.; Mas, S.; Sanz, A.B.; Lorenzo, O.; Ruiz-Ortega, M.; Opazo, L.; Mezzano, S.; Egido, J. Targeting inflammation in diabetic nephropathy: A tale of hope. Expert. Opin. Investig. Drugs 2018, 27, 917-930. [CrossRef] [PubMed]

192. Qiu, Y.-y.; Tang, L.-q. Roles of the NLRP3 inflammasome in the pathogenesis of diabetic nephropathy. Pharmacol. Res. 2016, 114, 251-264. [CrossRef]

193. Chaurasia, S.S.; Lim, R.R.; Parikh, B.H.; Wey, Y.S.; Tun, B.B.; Wong, T.Y.; Luu, C.D.; Agrawal, R.; Ghosh, A.; Mortellaro, A.; et al. The NLRP3 Inflammasome May Contribute to Pathologic Neovascularization in the Advanced Stages of Diabetic Retinopathy. Sci. Rep. 2018, 8, 1-15. [CrossRef]

194. Chen, H.; Zhang, X.; Liao, N.; Mi, L.; Peng, Y.; Liu, B.; Zhang, S.; Wen, F. Enhanced Expression of NLRP3 Inflammasome-Related Inflammation in Diabetic Retinopathy. Investig. Ophthalmol. Vis. Sci. 2018, 59, 978-985. [CrossRef]

195. Hou, Y.; Lin, S.; Qiu, J.; Sun, W.; Dong, M.; Xiang, Y.; Wang, L.; Du, P. NLRP3 inflammasome negatively regulates podocyte autophagy in diabetic nephropathy. Biochem. Biophys. Res. Commun. 2020, 521, 791-798. [CrossRef] [PubMed]

196. Wang, S.; Li, Y.; Fan, J.; Zhang, X.; Luan, J.; Bian, Q.; Ding, T.; Wang, Y.; Wang, Z.; Song, P.; et al. Interleukin-22 ameliorated renal injury and fibrosis in diabetic nephropathy through inhibition of NLRP3 inflammasome activation. Cell Death Dis. 2017, 8, e2937. [CrossRef]

197. Wu, M.; Han, W.; Song, S.; Du, Y.; Liu, C.; Chen, N.; Wu, H.; Shi, Y.; Duan, H. NLRP3 deficiency ameliorates renal inflammation and fibrosis in diabetic mice. Mol. Cell. Endocrinol. 2018, 478, 115-125. [CrossRef]

198. Hickson, L.T.J.; Langhi Prata, L.G.P.; Bobart, S.A.; Evans, T.K.; Giorgadze, N.; Hashmi, S.K.; Herrmann, S.M.; Jensen, M.D.; Jia, Q.; Jordan, K.L.; et al. Senolytics decrease senescent cells in humans: Preliminary report from a clinical trial of Dasatinib plus Quercetin in individuals with diabetic kidney disease. EBioMedicine 2019, 47, 446-456. [CrossRef]

199. Corcoran, S.E.; Halai, R.; Cooper, M.A. Pharmacological Inhibition of the Nod-Like Receptor Family Pyrin Domain Containing 3 Inflammasome with MCC950. Pharmacol. Rev. 2021, 73, 968-1000. [CrossRef] [PubMed]

200. Masson, W.; Lobo, M.; Barbagelata, L.; Lavalle-Cobo, A.; Molinero, G. Effect of anti-inflammatory therapy on major cardiovascular events in patients with diabetes: A meta-analysis. Diabetes Metab. Syndr. Clin. Res. Rev. 2021, 15, 102164. [CrossRef] 
201. Tittarelli, A. Connexin channels modulation in pathophysiology and treatment of immune and inflammatory disorders. Biochim. Biophys. Acta Mol. Basis Dis. 2021, 1867, 166258. [CrossRef] [PubMed]

202. Price, G.W.; Potter, J.A.; Williams, B.M.; Cliff, C.L.; Squires, P.E.; Hills, C.E. Connexin-mediated cell communication in the kidney: A potential therapeutic target for future intervention of diabetic kidney disease? Joan Mott Prize Lecture. Exp. Physiol. 2020, 105, 219-229. [CrossRef] 